\title{
Analysis of the Impact of the Decline in Crude Oil Imports on the Japanese Economy
}

\author{
Akiko Higashi-Shiraishi \\ Mitsubishi Research Institute, Inc., Tokyo, Japan
}

\begin{abstract}
In Japan, crude oil use depends almost exclusively on imports, mainly from the Middle East. Therefore, guaranteeing crude oil imports is an important issue for the Japanese energy policy. To analyze the impact of a decrease in crude oil imports, two features of crude oil as an energy good should be taken into consideration, namely being a factor of production in the energy sector and feedstock in petroleum and coal products. This study uses the GTAP and GTAP-E models to evaluate the impact of the decrease in crude oil imports in Japan, applying the same methodology and exogenous values, and analyzes the difference of the simulation results between the two models. In Japan, crude oil is used in two sectors: as feedstock in petroleum and coal products, and as a factor of production in the electricity sector. When energy goods are used as feedstock, the GTAP model, in which energy goods are treated as intermediate inputs with fixed coefficients, is suitable for analysis. The GTAP-E model, which incorporates an energy substitution structure into the GTAP model, is, on the other hand, suitable for analyzing energy goods when they are used as a factor of production. Furthermore, this study uses both a static analysis and an analysis incorporating capital accumulation effects to evaluate short-term, as well as medium to long-term impacts. The simulation results clearly indicate that, in the GTAP-E model, when crude oil imports from the Middle East decrease, Japan attempts to increase its crude oil imports from other regions, but by less than in the case of the GTAP model. The results of this study show that, for energy goods used mainly as feedstock, such as crude oil, analysis with fixed coefficients presents more realistic simulation results than those using the energy substitution structure.
\end{abstract}

Keywords: GTAP Model, energy substitution, fixed coefficients, Japanese energy policy, capital accumulation effects, crude oil imports

\section{Introduction}

In Japan, the use of crude oil depends almost exclusively on imports, and is used in two sectors: mainly as feedstock in the petroleum and coal products sector (94\%), and as a factor of production in the electricity sector (6\%). Considering that petroleum and coal products, and electricity are used as factors of production in all Japanese industries, and because changing the structure of industrial use of energy goods is a lengthy process, guaranteeing crude oil imports and evaluating the impact of the decline in crude oil imports are important issues in Japan. Typically, CGE models used for the analysis of supply shortage of energy commodity effects

\footnotetext{
Akiko Higashi-Shiraishi, Ph.D. in Economics, Senior Economist, Mitsubishi Research Institute, Inc., Tokyo, Japan.

Correspondence concerning this article should be addressed to Akiko Higashi-Shiraishi, 2-10-3 Nagatacho, Chiyoda-ku, Tokyo 100-8141, Japan.
} 
incorporate an energy substitution structure. However, in the case of energy goods used as feedstock, in which the chemical content is transformed to become part of the output commodity, such as crude oil, CGE models with fixed coefficients should be used, as Fujikawa (1999) points out.

After analyzing the GTAP 9 Database concerning Japanese energy use and describing the methodology of analyzing the economic impact of the decrease in crude oil imports in Japan, this study investigates the impact of the decline in crude oil imports from the Middle East in Japan using the GTAP model, in which energy goods are treated as intermediate inputs with fixed coefficients, using static analysis. Next, it discusses the simulation results of the GTAP-E models following the same methodology and applying the same exogenous values as the simulation by the GTAP model. The comparison of the simulation results of the both models shows the reason why GTAP model should be used for the analysis of the energy goods used as feedstock rather than the GTAP-E model, which incorporates energy substitution structure and treats energy goods as factors of production. Furthermore, this study also compares the simulation results of the GTAP and the GTAP-E models using an analysis that incorporates the capital accumulation effects to evaluate medium to long-term impacts.

The analysis of the simulation results by the two models shows that when crude oil imports from the Middle East decrease, Japan would try to increase crude oil imports from other regions, but by less in the GTAP-E model, in which crude oil can be substituted by other energy goods, than in the case of the GTAP model. As a result, the production of petroleum and coal products, for which crude oil is important as feedstock, decrease more in the GTAP-E model than in the GTAP model and the decrease in industrial output and investment become more serious in the GTAP-E model than in the GTAP model.

As crude oil is used mainly as feedstock in Japan, when its imports from the Middle East decrease, Japan would try to increase its imports from other regions rather than to substitute other energy goods for crude oil. The comparison of the simulation results of the GTAP model and the GTAP-E model shows that it is suitable to use CGE model with fixed coefficients for analysis of energy goods use as feedstock.

\section{Analysis of Imports Data and Structure of Crude Oil in Japan}

\section{Japanese Data From the GTAP 9 Database on the Import of Crude Oil}

Table 1 shows the Japanese imports, at market prices, of energy goods (coal, oil, gas, petroleum, and coal products) taken from the GTAP 9 database. Table 2 shows the sources of Japanese imports of energy goods. The data in Table 2 show that almost $89 \%$ of crude oil is imported from the Middle East, along with $23.6 \%$ of imported gas and $53.1 \%$ of imported petroleum and coal products. In total, $61.7 \%$ of energy goods are imported from the Middle East. The Agency for Natural Resources and Energy (2014) points out the Japanese dependence on a limited number of energy resource supply areas, as well as the importance of increasing diversity in the procurement of these energy resources.

The data taken from the UN Comtrade database show that, in Japan, $82.7 \%$ of crude oil was imported from the Middle East in 2012, followed by $83.1 \%$ in both 2013 and 2014. Thus, until recently, the Middle East has been the main supplier of crude oil to Japan. 
Table 1

Japanese Import Data for Energy Goods (Millions, USD)

\begin{tabular}{|l|r|r|r|r|r|r|r|r|}
\hline & Oceania & China & Korea & $\begin{array}{c}\text { ASEAN } \\
\text { Net Energy } \\
\text { Exporters }\end{array}$ & $\begin{array}{c}\text { Other } \\
\text { ASEAN } \\
\text { countries }\end{array}$ & $\begin{array}{c}\text { Other } \\
\text { Asian } \\
\text { countries }\end{array}$ & India & $\begin{array}{c}\text { United } \\
\text { States }\end{array}$ \\
\hline Coal & 14,683 & 545 & 0 & 4,815 & 0 & 5 & 0 & 928 \\
\hline Oil & 483 & 13 & 0 & 5,215 & 4 & 14 & 0 & 0 \\
\hline Gas & 6,519 & 7 & 0 & 15,126 & 5 & 9 & 0 & 124 \\
\hline $\begin{array}{l}\text { Petroleum and } \\
\text { coal products }\end{array}$ & 1,568 & 2,093 & 7,076 & 1,143 & 1,403 & 372 & 2,820 & 1,856 \\
\hline Total & 23,253 & 2,658 & 7,076 & 26,299 & 1,412 & 400 & 2,820 & 2,908 \\
\hline
\end{tabular}

\begin{tabular}{|l|r|r|r|r|r|r||r|}
\hline & $\begin{array}{c}\text { Latin } \\
\text { America }\end{array}$ & EU28 & $\begin{array}{c}\text { Eastern } \\
\text { Europe and } \\
\text { FSU }\end{array}$ & Middle East & Africa & \multicolumn{1}{|c|}{$\begin{array}{c}\text { Rest of } \\
\text { World }\end{array}$} & Total \\
\hline Coal & 74 & 1 & 2,181 & 0 & 101 & 1,457 & 24,789 \\
\hline Oil & 172 & 28 & 5,667 & 118,231 & 3,382 & 30 & 133,238 \\
\hline Gas & 411 & 14 & 10,674 & 10,550 & 1,244 & 59 & 44,743 \\
\hline $\begin{array}{l}\text { Petroleum and } \\
\text { coal products }\end{array}$ & 145 & 339 & 1,389 & 23,504 & 373 & 154 & 44,233 \\
\hline Total & 802 & 382 & 19,911 & 152,285 & 5,100 & 1,700 & 247,003 \\
\hline
\end{tabular}

Source: GTAP 9 database.

Table 2

Sources of Japanese Imports of Energy Goods (Percentage)

\begin{tabular}{|l|r|r|r|r|r|r|r|r|}
\hline & Oceania & \multicolumn{1}{c|}{ China } & Korea & $\begin{array}{c}\text { ASEAN } \\
\text { Net Energy } \\
\text { Exporters }\end{array}$ & $\begin{array}{c}\text { Other } \\
\text { ASEAN } \\
\text { countries }\end{array}$ & $\begin{array}{c}\text { Other } \\
\text { Asian } \\
\text { countries }\end{array}$ & India & $\begin{array}{c}\text { United } \\
\text { States }\end{array}$ \\
\hline Coal & $59.2 \%$ & $2.2 \%$ & $0.0 \%$ & $19.4 \%$ & $0.0 \%$ & $0.0 \%$ & $0.0 \%$ & $3.7 \%$ \\
\hline Oil & $0.4 \%$ & $0.0 \%$ & $0.0 \%$ & $3.9 \%$ & $0.0 \%$ & $0.0 \%$ & $0.0 \%$ & $0.0 \%$ \\
\hline $\begin{array}{l}\text { Getroleum and } \\
\text { coal products }\end{array}$ & $14.6 \%$ & $0.0 \%$ & $0.0 \%$ & $33.8 \%$ & $0.0 \%$ & $0.0 \%$ & $0.0 \%$ & $0.3 \%$ \\
\hline Total & $3.5 \%$ & $4.7 \%$ & $16.0 \%$ & $2.6 \%$ & $3.2 \%$ & $0.8 \%$ & $6.4 \%$ & $4.2 \%$ \\
\hline
\end{tabular}

\begin{tabular}{|l|r|r|r|r|r|r||r|}
\hline & $\begin{array}{r}\text { Latin } \\
\text { America }\end{array}$ & \multicolumn{1}{|c|}{ EU28 } & $\begin{array}{c}\text { Eastern } \\
\text { Europe and } \\
\text { FSU }\end{array}$ & Middle East & Africa & \multicolumn{1}{|c|}{$\begin{array}{l}\text { Rest of } \\
\text { World }\end{array}$} & Total \\
\hline Coal & $0.3 \%$ & $0.0 \%$ & $8.8 \%$ & $0.0 \%$ & $0.4 \%$ & $5.9 \%$ & $100.0 \%$ \\
\hline Oil & $0.1 \%$ & $0.0 \%$ & $4.3 \%$ & $88.7 \%$ & $2.5 \%$ & $0.0 \%$ & $100.0 \%$ \\
\hline Gas & $0.9 \%$ & $0.0 \%$ & $23.9 \%$ & $23.6 \%$ & $2.8 \%$ & $0.1 \%$ & $100.0 \%$ \\
\hline $\begin{array}{l}\text { Petroleum and } \\
\text { coal products }\end{array}$ & $0.3 \%$ & $0.8 \%$ & $3.1 \%$ & $53.1 \%$ & $0.8 \%$ & $0.3 \%$ & $100.0 \%$ \\
\hline Total & $0.3 \%$ & $0.2 \%$ & $8.1 \%$ & $61.7 \%$ & $2.1 \%$ & $0.7 \%$ & $100.0 \%$ \\
\hline
\end{tabular}

Source: GTAP 9 database.

\section{Japanese Data From the GTAP 9 Database on the Industrial Use of Crude Oil}

Table 3 shows the data on Japanese firms' domestic purchases, taken from the GTAP 9 database, illustrating that little domestic coal, crude oil, and gas are used in Japanese industries. 
Table 3

Japanese Firms' Domestic Purchases Data (Millions, USD)

\begin{tabular}{|l|r|r|r|r|r|r|r|}
\hline & Agriculture & Coal & Oil & Gas & $\begin{array}{l}\text { Petroleum and } \\
\text { coal products }\end{array}$ & Electricity & $\begin{array}{l}\text { Manufacturing } \\
\text { sectors }\end{array}$ \\
\hline Agriculture & 12,086 & 1 & 0 & 0 & 1 & 1 & 64,049 \\
\hline Coal & 0 & 0 & 0 & 0 & 3 & 26 & 71 \\
\hline Oil & 0 & 0 & 0 & 0 & 469 & 58 & 6 \\
\hline Gas & 0 & 0 & 0 & 0 & 6 & 0 & 12 \\
\hline $\begin{array}{l}\text { Petroleum and } \\
\text { coal products }\end{array}$ & 5,839 & 0 & 0 & 69,168 & 26,889 & 51,392 \\
\hline Electricity & 214 & 1 & 0 & 4 & 3,099 & 8,574 & 61,602 \\
\hline $\begin{array}{l}\text { Manufacturing } \\
\text { goods }\end{array}$ & 22,524 & 9 & 33 & 70 & 4,998 & 2,478 & $1,289,128$ \\
\hline Services & 20,190 & 39 & 189 & 1,061 & 8,356 & 49,303 & 672,979 \\
\hline \hline TOTAL & 60,853 & 49 & 223 & 1,141 & 66,094 & 87,330 & $2,139,238$ \\
\hline
\end{tabular}

\begin{tabular}{|c|c|c|}
\hline & $\begin{array}{l}\text { Services } \\
\text { sectors }\end{array}$ & TOTAL \\
\hline Agriculture & 13,950 & 90,088 \\
\hline Coal & 6 & 107 \\
\hline Oil & 0 & 533 \\
\hline Gas & 89 & 101 \\
\hline $\begin{array}{l}\text { Petroleum and } \\
\text { coal products }\end{array}$ & 91,127 & 224,421 \\
\hline Electricity & 80,875 & 154,368 \\
\hline $\begin{array}{l}\text { Manufacturing } \\
\text { goods }\end{array}$ & 598,009 & $1,917,249$ \\
\hline Services & $2,057,743$ & $2,809,859$ \\
\hline$\overline{\text { TOTAL }}$ & $2,841,798$ & $\overline{5,196,726}$ \\
\hline
\end{tabular}

Source: GTAP 9 database.

Table 4 shows the data on Japanese firms' imports, taken from the GTAP 9 database. As shown, imports of crude oil are considerably larger than those of other energy goods. The value of crude oil imports is almost USD 133 billion, while the value of domestic crude oil remains USD 533 million, as shown in Table 3. This shows that Japan depends significantly on crude oil imports. The values of imported petroleum and coal products are much less than those of domestic petroleum and coal products, which shows that they are produced mainly in Japan. Then, a comparison of Table 3 and Table 4 shows that electricity is produced exclusively in Japan. Petroleum and coal products and electricity are used primarily within the manufacturing and service sectors.

Table 5 shows the shares of Japanese firms' imports, calculated from the GTAP 9 database. With regard to crude oil, $94.1 \%$ is used in the petroleum and coal products sector, and 5.9\% is used in electricity sector.

Table 6 shows Japanese firms' total intermediate goods, calculated from the GTAP 9 database. Petroleum and coal products have the largest values among the energy goods, and are used in many sectors as a factor of production. Table 7 shows the shares of Japanese firms' total intermediate goods used in the industrial sectors, calculated from the GTAP 9 database. Because the use of crude oil depends on imports, the shares of crude oil in Japanese firms' total intermediate goods are the same as those of imports. As much as $94.1 \%$ of crude oil is used in the petroleum and coal products sector, mostly as feedstock, and 5.9\% is used in the electricity sector as a factor of production. 
Table 4

Japanese Firms' Import Data (Millions, USD)

\begin{tabular}{|l|r|l|r|r|r|r|r|}
\hline & Agriculture & Coal & Oil & Gas & $\begin{array}{l}\text { Petroleum and } \\
\text { coal products }\end{array}$ & Electricity & $\begin{array}{l}\text { Manufacturing } \\
\text { sectors }\end{array}$ \\
\hline Agriculture & 1,812 & 0 & 0 & 0 & 8 & 22,483 \\
\hline Coal & 0 & 0 & 0 & 0 & 10,329 & 12,279 & 2,062 \\
\hline Oil & 0 & 0 & 0 & 4 & 125,379 & 7,842 & 11 \\
\hline Gas & 0 & 0 & 0 & 49 & 4,781 & 28,030 & 3,696 \\
\hline $\begin{array}{l}\text { Petroleum and } \\
\text { coal products }\end{array}$ & 161 & 0 & 0 & 5 & 4,151 & 2,432 & 25,184 \\
\hline Electricity & 0 & 0 & 0 & 0 & 0 & 0 & \\
\hline $\begin{array}{l}\text { Manufacturing } \\
\text { goods }\end{array}$ & 2,000 & 0 & 1 & 4 & 135 & 452 & 263,659 \\
\hline Services & 620 & 1 & 10 & 13 & 146 & 751 & 14,900 \\
\hline \hline TOTAL & 4,594 & 1 & 11 & 75 & 144,930 & 51,787 & 331,997 \\
\hline
\end{tabular}

\begin{tabular}{|c|c|c|}
\hline & $\begin{array}{l}\text { Services } \\
\text { sectors }\end{array}$ & |TOTAL \\
\hline Agriculture & 2,707 & 27,011 \\
\hline Coal & 116 & 24,787 \\
\hline Oil & 1 & 133,238 \\
\hline Gas & 7,376 & 43,933 \\
\hline $\begin{array}{l}\text { Petroleum and } \\
\text { coal products }\end{array}$ & 8,916 & 40,849 \\
\hline Electricity & 1 & 2 \\
\hline $\begin{array}{l}\text { Manufacturing } \\
\text { goods }\end{array}$ & 84,891 & 351,143 \\
\hline Services & 75,932 & 92,373 \\
\hline TOTAL & 179,940 & 713,334 \\
\hline
\end{tabular}

Source: GTAP 9 database.

Table 5

Shares of Japanese Firms' Imports (Percentage)

\begin{tabular}{|c|c|c|c|c|c|c|c|}
\hline & Agriculture & Coal & Oil & Gas & $\begin{array}{l}\text { Petroleum and } \\
\text { coal products }\end{array}$ & Electricity & $\begin{array}{l}\text { Manufacturing } \\
\text { sectors }\end{array}$ \\
\hline \begin{tabular}{|l|} 
Agriculture \\
\end{tabular} & $6.7 \%$ & $0.0 \%$ & $0.0 \%$ & $0.0 \%$ & $0.0 \%$ & $0.0 \%$ & $83.2 \%$ \\
\hline Coal & $0.0 \%$ & $0.0 \%$ & $0.0 \%$ & $0.0 \%$ & $41.7 \%$ & $49.5 \%$ & $8.3 \%$ \\
\hline Oil & $0.0 \%$ & $0.0 \%$ & $0.0 \%$ & $0.0 \%$ & $94.1 \%$ & $5.9 \%$ & $0.0 \%$ \\
\hline Gas & $0.0 \%$ & $0.0 \%$ & $0.0 \%$ & $0.1 \%$ & $10.9 \%$ & $63.8 \%$ & $8.4 \%$ \\
\hline $\begin{array}{l}\text { Petroleum and } \\
\text { coal products } \\
\end{array}$ & $0.4 \%$ & $0.0 \%$ & $0.0 \%$ & $0.0 \%$ & $10.2 \%$ & $6.0 \%$ & $61.7 \%$ \\
\hline \begin{tabular}{|l|} 
Electricity \\
\end{tabular} & $0.0 \%$ & $0.0 \%$ & $0.0 \%$ & $0.0 \%$ & $0.0 \%$ & $6.3 \%$ & $37.5 \%$ \\
\hline \begin{tabular}{|l} 
Manufacturing \\
goods
\end{tabular} & $0.6 \%$ & $0.0 \%$ & $0.0 \%$ & $0.0 \%$ & $0.0 \%$ & $0.1 \%$ & $75.1 \%$ \\
\hline Services & $0.7 \%$ & $0.0 \%$ & $0.0 \%$ & $0.0 \%$ & $0.2 \%$ & $0.8 \%$ & $16.1 \%$ \\
\hline TOTAL & $0.6 \%$ & $0.0 \%$ & $0.0 \%$ & $0.0 \%$ & $20.3 \%$ & $7.3 \%$ & $46.5 \%$ \\
\hline
\end{tabular}

\begin{tabular}{|c|c|c|}
\hline & \begin{tabular}{|l|} 
Services \\
sectors
\end{tabular} & TOTAL \\
\hline Agriculture & $10.0 \%$ & $100.0 \%$ \\
\hline Coal & $0.5 \%$ & $100.0 \%$ \\
\hline Oil & $0.0 \%$ & $100.0 \%$ \\
\hline Gas & $16.8 \%$ & $100.0 \%$ \\
\hline $\begin{array}{l}\text { Petroleum and } \\
\text { coal products }\end{array}$ & $21.8 \%$ & $100.0 \%$ \\
\hline \begin{tabular}{|l|} 
Electricity \\
\end{tabular} & $56.3 \%$ & $100.0 \%$ \\
\hline \begin{tabular}{|l} 
Manufacturing \\
goods
\end{tabular} & $24.2 \%$ & $100.0 \%$ \\
\hline Services & $82.2 \%$ & $100.0 \%$ \\
\hline TOTAL & $25.2 \%$ & $100.0 \%$ \\
\hline
\end{tabular}

Source: GTAP 9 database. 
Table 6

Japanese Firms' Total Intermediate Goods Data (Millions, USD)

\begin{tabular}{|l|r|r|r|r|r|r|}
\hline & Agriculture & Coal & Oil & Gas & $\begin{array}{l}\text { Petroleum } \\
\text { and coal }\end{array}$ & Electricity \\
\hline Agriculture & 13,898 & 1 & 0 & 0 & 9 & 2 \\
\hline Coal & 0 & 0 & 0 & 0 & 10,332 & 12,306 \\
\hline Oil & 0 & 0 & 0 & 4 & 125,848 & 7,900 \\
\hline Gas & 0 & 0 & 0 & 49 & 4,781 & 28,030 \\
\hline $\begin{array}{l}\text { Petroleum and coal } \\
\text { products }\end{array}$ & 6,000 & 0 & 0 & 11 & 53,319 & 29,321 \\
\hline Electricity & 214 & 1 & 0 & 4 & 3,099 & 8,574 \\
\hline Manufacturing goods & 24,525 & 9 & 34 & 74 & 5,133 & 2,930 \\
\hline Services & 20,811 & 40 & 199 & 1,074 & 8,502 & 50,054 \\
\hline \hline TOTAL & 65,448 & 50 & 234 & 1,216 & 211,023 & 139,117 \\
\hline
\end{tabular}

\begin{tabular}{|l|r|r||r|}
\hline & $\begin{array}{r}\text { Manufacturing } \\
\text { sectors }\end{array}$ & $\begin{array}{c}\text { Services } \\
\text { sectors }\end{array}$ & \multicolumn{1}{|c|}{ TOTAL } \\
\hline Agriculture & 86,532 & 16,656 & 117,099 \\
\hline Coal & 2,134 & 122 & 24,893 \\
\hline Oil & 17 & 1 & 133,771 \\
\hline Gas & 3,709 & 7,464 & 44,034 \\
\hline $\begin{array}{l}\text { Petroleum and coal } \\
\text { products }\end{array}$ & 76,576 & 100,043 & 265,270 \\
\hline Electricity & 61,602 & 80,876 & 154,370 \\
\hline Manufacturing goods & $1,552,787$ & 682,900 & $2,268,392$ \\
\hline Services & 687,878 & $2,133,675$ & $2,902,232$ \\
\hline \hline TOTAL & $2,471,235$ & $3,021,738$ & $5,910,061$ \\
\hline
\end{tabular}

Source: GTAP 9 database.

Table 7

Shares of Japanese Firms' Total Intermediate Goods Used in the Industrial Sectors (Percentage)

\begin{tabular}{|l|r|r|r|r|r|r|}
\hline & Agriculture & \multicolumn{1}{c|}{ Coal } & \multicolumn{1}{c|}{ Oil } & \multicolumn{1}{c|}{ Gas } & $\begin{array}{r}\text { Petroleum } \\
\text { and coal }\end{array}$ & \multicolumn{1}{c|}{ Electricity } \\
\hline Agriculture & $11.9 \%$ & $0.0 \%$ & $0.0 \%$ & $0.0 \%$ & $0.0 \%$ & $0.0 \%$ \\
\hline Coal & $0.0 \%$ & $0.0 \%$ & $0.0 \%$ & $0.0 \%$ & $41.5 \%$ & $49.4 \%$ \\
\hline Oil & $0.0 \%$ & $0.0 \%$ & $0.0 \%$ & $0.0 \%$ & $94.1 \%$ & $5.9 \%$ \\
\hline Gas & $0.0 \%$ & $0.0 \%$ & $0.0 \%$ & $0.1 \%$ & $10.9 \%$ & $63.7 \%$ \\
\hline $\begin{array}{l}\text { Petroleum and coal } \\
\text { products }\end{array}$ & $2.3 \%$ & $0.0 \%$ & $0.0 \%$ & $0.0 \%$ & $20.1 \%$ & $11.1 \%$ \\
\hline Electricity & $0.1 \%$ & $0.0 \%$ & $0.0 \%$ & $0.0 \%$ & $2.0 \%$ & $5.6 \%$ \\
\hline Manufacturing goods & $1.1 \%$ & $0.0 \%$ & $0.0 \%$ & $0.0 \%$ & $0.2 \%$ & $0.1 \%$ \\
\hline Services & $0.7 \%$ & $0.0 \%$ & $0.0 \%$ & $0.0 \%$ & $0.3 \%$ & $1.7 \%$ \\
\hline \hline TOTAL & $1.1 \%$ & $0.0 \%$ & $0.0 \%$ & $0.0 \%$ & $3.6 \%$ & $2.4 \%$ \\
\hline
\end{tabular}

\begin{tabular}{|l|r|r||r|}
\hline & $\begin{array}{c}\text { Manufacturing } \\
\text { sectors }\end{array}$ & $\begin{array}{c}\text { Services } \\
\text { sectors }\end{array}$ & \multicolumn{1}{c|}{ TOTAL } \\
\hline Agriculture & $73.9 \%$ & $14.2 \%$ & $100.0 \%$ \\
\hline Coal & $8.6 \%$ & $0.5 \%$ & $100.0 \%$ \\
\hline Oil & $0.0 \%$ & $0.0 \%$ & $100.0 \%$ \\
\hline Gas & $8.4 \%$ & $17.0 \%$ & $100.0 \%$ \\
\hline $\begin{array}{l}\text { Petroleum and coal } \\
\text { products }\end{array}$ & $28.9 \%$ & $37.7 \%$ & $100.0 \%$ \\
\hline Electricity & $39.9 \%$ & $52.4 \%$ & $100.0 \%$ \\
\hline Manufacturing goods & $68.5 \%$ & $30.1 \%$ & $100.0 \%$ \\
\hline Services & $23.7 \%$ & $73.5 \%$ & $100.0 \%$ \\
\hline \hline TOTAL & $41.8 \%$ & $51.1 \%$ & $100.0 \%$ \\
\hline
\end{tabular}

Source: GTAP 9 database. 
This data analysis shows that the Japanese industrial use of primary energy goods depends almost completely on imports. Therefore, Japan is vulnerable to changes in the international energy situation.

To overcome this vulnerability, the Japanese third strategic energy plan, published in 2010, set as a major objective enhancing energy self-sufficiency. However, after the Great East Japan Earthquake in 2011, Japan was again forced to make significant adjustments to its energy policy. The fourth strategic energy plan, published in April 2014, set four major objectives: energy security, economic efficiency, the environment, and safety.

\section{Literature Review}

The analysis of the decrease in crude oil imports, which would cause a supply shortage, could be considered as an analysis of energy commodity supply shortage. CGE models, which can perform both macroeconomic analysis and analysis by commodity, are often used to analyze the impact of energy commodity supply shortages. Studies, such as Rose and Guha (2004), Guha (2005), Rose and Liao (2005), Tatano, Tsuchiya, and Kajitani (2007), use the CGE model in economic analyses of disasters, in which lifeline disruptions and supply shortages of energy goods occur. In Japan, the impact of electric supply shortages caused by the Great East Japan Earthquake has been analyzed using CGE models (e.g., see Ishikura \& Ishikawa, (2011); Yamazaki \& Ochiai, 2011; Tachi \& Ochiai, 2011; Higashi-Shiraishi, 2014).

In the CGE model, with analyses in the energy and environment fields, energy goods should be treated as factors of production. When supply shortage of some energy commodity occurs, whether or not the structure of the substitution between capital and energy goods, and between energy goods themselves exists, affects simulation results. Therefore, CGE models used in the studies cited above incorporate the structures of energy substitution.

However, some energy goods are used not as factors of production, but as feedstock. Burniaux and Truong (2002) note that, among energy goods, coal, gas, and crude oil could be referred to as primary energy. These goods can be thus used as inputs for various industrial and household activities (e.g., natural gas, as an energy source for electricity production, and coal, as an energy source for steel production) and as "feedstock." As examples of energy goods used as feedstock, Burniaux and Truong (2002) include natural gas, used as feedstock in the fertilizer industry, crude oil, used as feedstock in the petroleum refinery industry, and coke used as feedstock in steel production. Fujikawa (1999) states that energy commodities used as feedstock, such as the coke used in steel production, and the crude oil used in gasoline production, should be analyzed not within the energy substitution structure, but with fixed coefficients.

The GTAP-E model, which is used in the analysis of this study, is an extended energy-environment version of the GTAP model developed in 2002, as to incorporate an energy substitution structure in the GTAP model. Compared with the standard GTAP model, whose structure is explained in Hertel (1997), the main feature of the GTAP-E model is its production structure with energy substitution, namely, inter-fuel substitution and fuel-factor substitution. In the GTAP model, energy goods are treated as intermediate inputs only with fixed coefficients.

When energy goods are used as factors of production, as in the case of electricity, the effect of substitution between capital and energy goods becomes important. This is illustrated in Higashi (2016), who analyzes the effect of the electricity supply shortage in Japan caused by the Great East Japan Earthquake. On the other hand, when energy goods are used as feedstock, as in the case of crude oil used in petroleum and coal products, we 
should consider that its chemical content is mainly transformed to become part of the output commodity, and analyze it with fixed coefficients, as Fujikawa (1999) points out.

Concerning the analysis of energy commodity supply shortage, mainly CGE models with energy substitution structure have been hitherto used. This study analyzes the impacts of the decline in crude oil imports in Japan, using the GTAP model with fixed coefficients. Furthermore, it identifies why the GTAP model should be used for the analysis of energy goods used as feedstock, rather than the GTAP-E model with its energy substitution structure, following the methodology used in Higashi-Shiraishi (2014), which compares the simulation results of the GTAP and GTAP-E models.

\section{Research Methods}

\section{Difference in the Production and Consumption Structure Between the GTAP Model and the GTAP-E Model}

Compared with the standard GTAP model, whose structure is explained in Hertel (1997), the main feature of the GTAP-E model is its production structure with energy substitution, namely, inter-fuel substitution and fuel-factor substitution. In the GTAP-E model, energy goods are taken from the intermediate input nest and placed in the value-added nest, forming capital-energy sub-production. Capital-energy sub-production is classified as follows: energy sub-production, which includes electricity and non-electricity energy goods; non-electricity energy sub-production, which includes coal and non-coal energy goods; and non-coal energy sub-production, which includes crude oil, gas, and petroleum and coal products.

This structure of substitution between capital and energy goods and between the energy goods themselves is suitable for analyzing crude oil imports when they are used as factors of production, that is, when used in the electricity sector. In the GTAP model, energy goods are treated as intermediate inputs only. This would be suitable for analyzing crude oil imports when they are used as intermediate inputs (i.e., as feedstock), in which the chemical content is transformed to become part of the output commodity, as described in Burniaux and Truong (2002). Burniaux and Truong (2002) note that among energy goods, coal, gas, and crude oil could be referred to as primary energy. These goods can be used as inputs for various industrial and household activities (e.g., natural gas, to provide the energy source for electricity production; and coal, as an energy source for steel making) and as "feedstock". As examples of energy goods used as feedstock, Burniaux and Truong (2002) include natural gas used as feedstock in fertilizer, crude oil used as feedstock in the petroleum refinery industry, and coke used as feedstock in steel production. In addition, Fujikawa (1999) states that coke used in steel production, and crude oil used in gasoline production are examples of energy goods that should be analyzed with fixed coefficients.

When energy goods are used as factors of production, as in the case of electricity, the effect of the substitution between capital and energy goods becomes important. This is illustrated in Higashi (2016), who analyzes the effect of the electricity supply shortage in Japan caused by the Great East Japan Earthquake. On the other hand, when energy goods are used as feedstock, as in the case of the crude oil used in petroleum and coal products, its chemical content is mostly transformed to become part of the output commodity. Therefore, these energy goods should be analyzed with fixed coefficients, as Fujikawa (1999) points out.

The production structure of the GTAP model is illustrated in Figure 1, while Figure 2 provides the GTAP-E production structure, and Figure 3 shows the GTAP-E capital-energy composite structure. 
Private household consumption is structured according to the constant difference of elasticities (CDE) functional form in the GTAP model. In the GTAP-E model, the main feature of private consumption is that commodities are divided into two groups: energy goods and non-energy goods. The energy commodities are aggregated into a single composite, which remains in the CDE structure and with the same CDE parameter values. To allow for flexible substitution between the individual energy commodities, the energy composite is specified as a CES sub-structure with a substitution elasticity value of 1 .

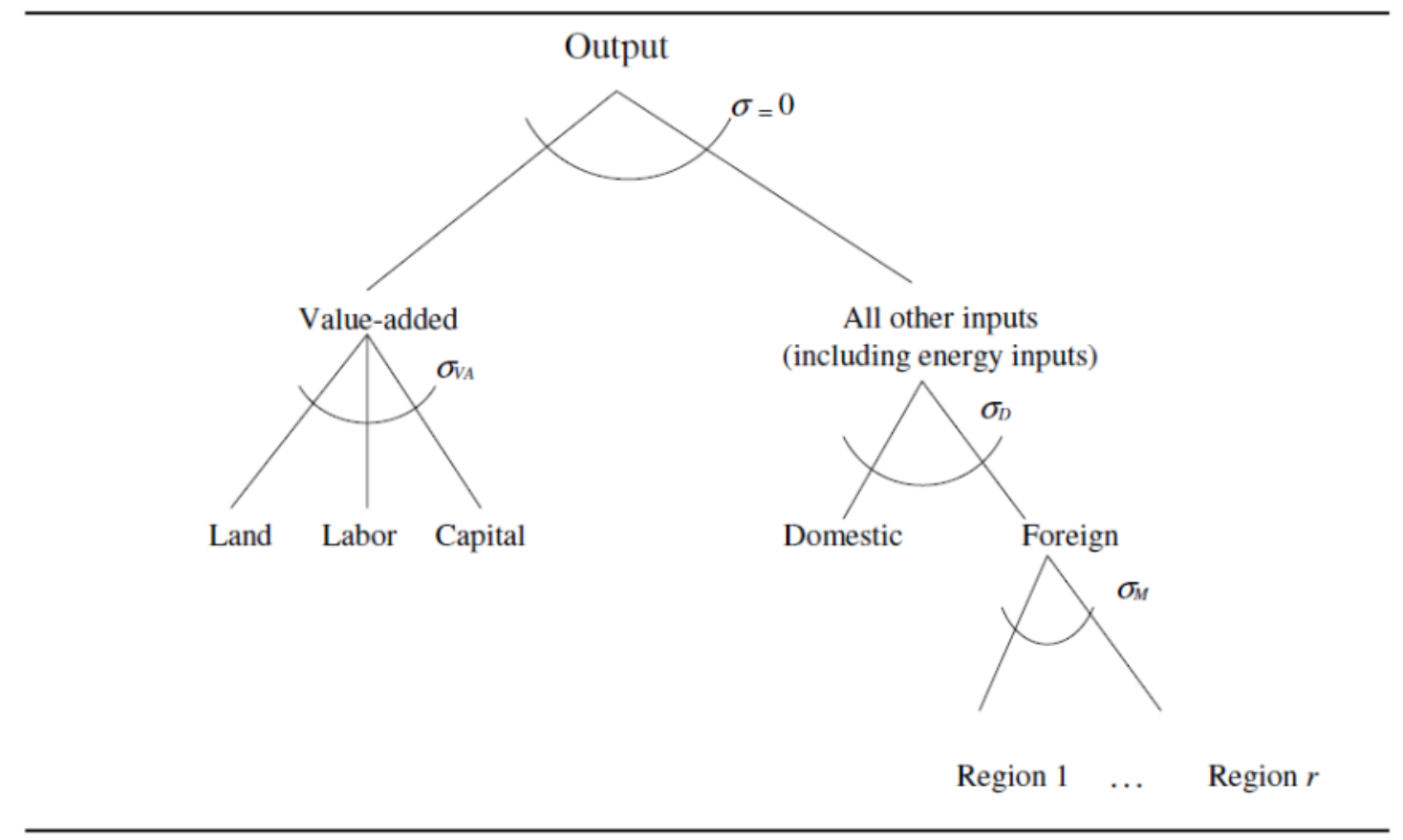

Figure 1. Standard GTAP production structure. Source: Burniaux and Truong (2002), Figure 15, p. 30.

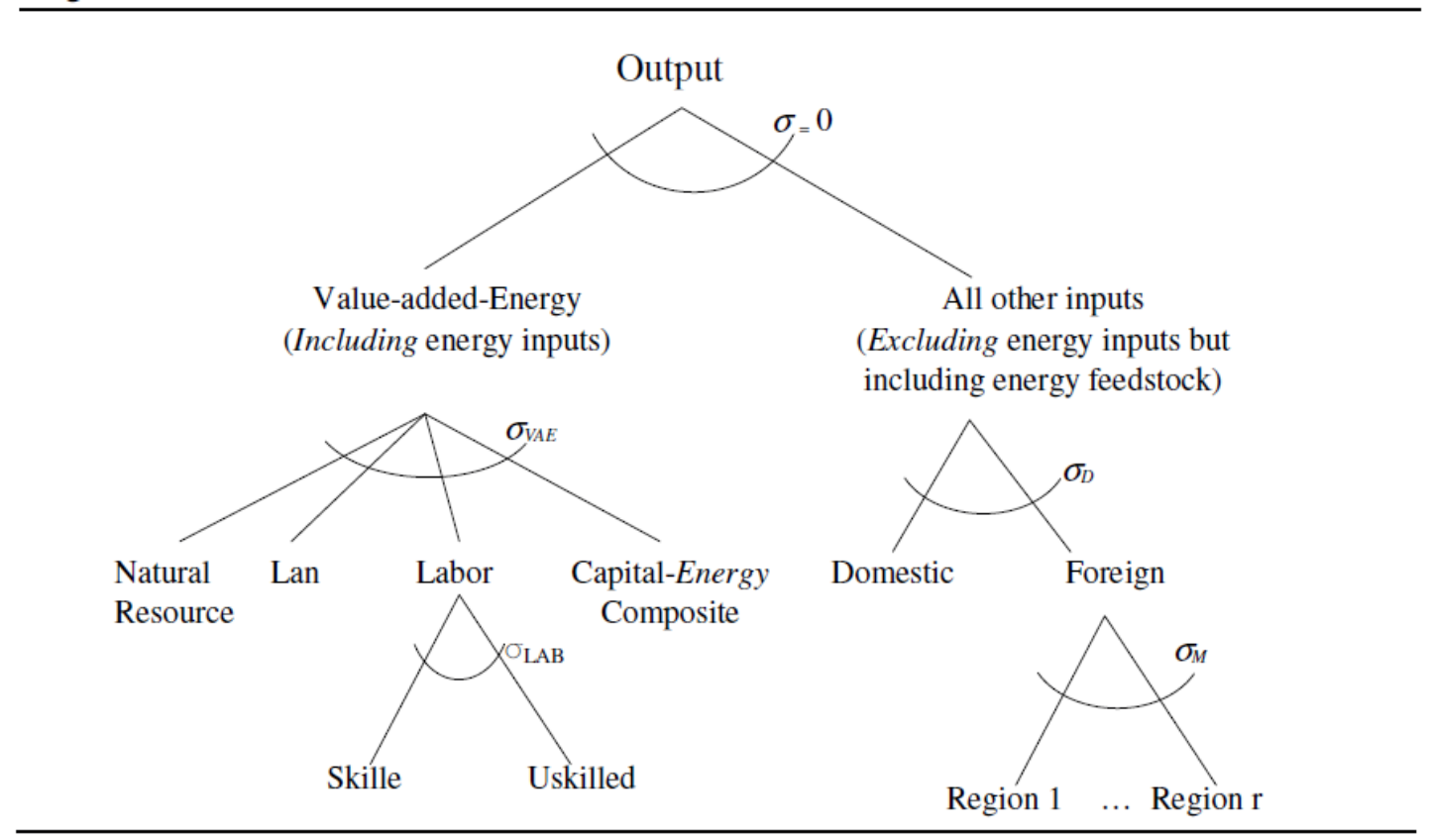

Figure 2. GTAP-E production structure. Source: Burniaux and Truong (2002), Figure 16, p. 31. 


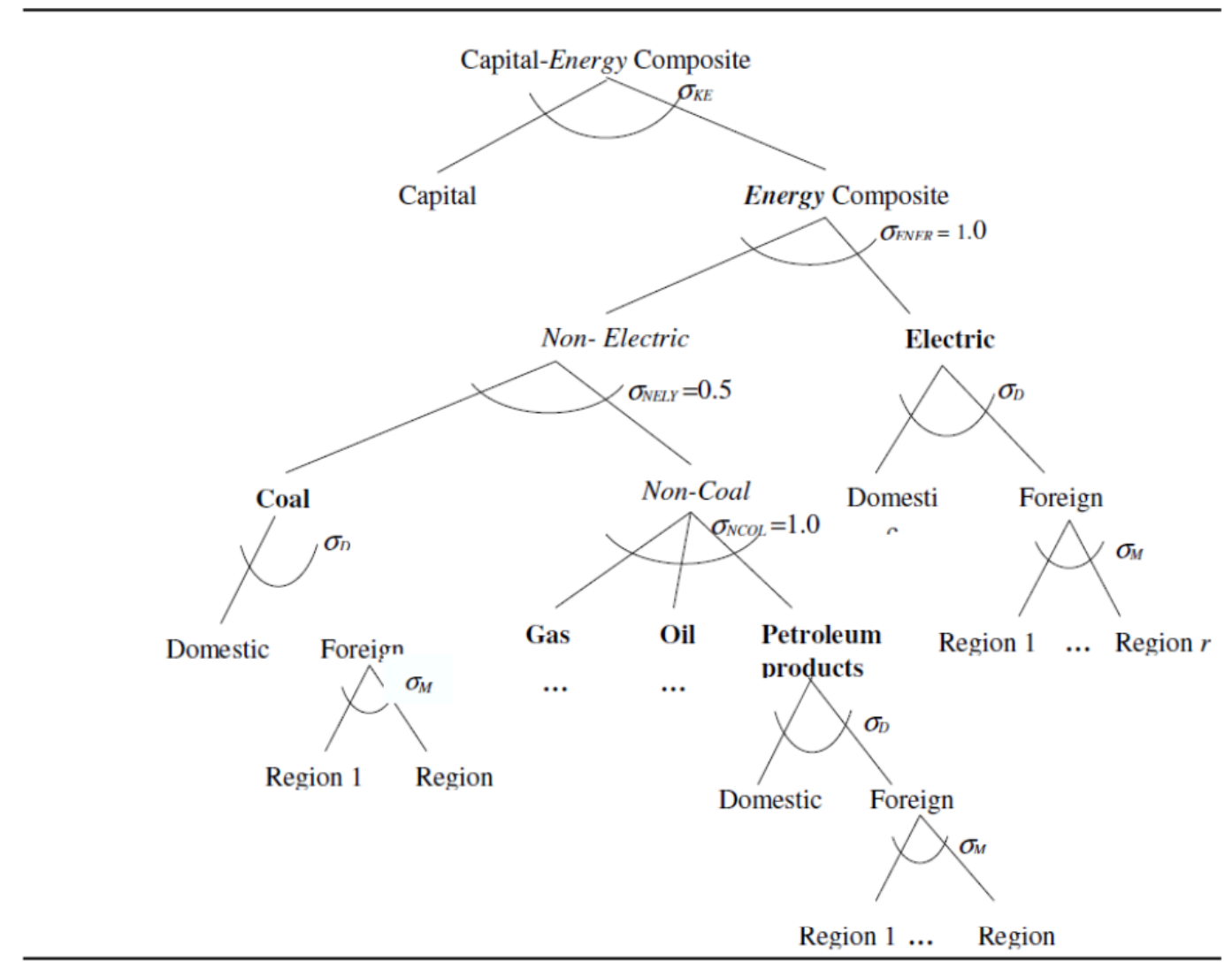

Figure 3. GTAP-E capital-energy composite structure. Source: Burniaux and Truong (2002), Figure 17, p. 31.

Government consumption is assumed to be a Cobb-Douglas structure in the GTAP model, with a substitution elasticity value of 1 for all commodities. The main feature of government consumption in the GTAP-E model is that commodities are again divided into two groups: an energy-goods composite and a non-energy-goods composite, with a substitution elasticity value of 1 in both cases. At the top of the government consumption nest in the GTAP-E model, the substitution elasticity takes a value of 0.5 .

The private consumption structure of the GTAP-E model is provided in Figure 4, while Figure 5 provides the GTAP-E government consumption structure.

\section{Methodology for Analyzing the Economic Impacts of the Decrease in Crude Oil Imports Using the GTAP Model and the GTAP-E Model}

This study analyzes the economic impact of the decrease in crude oil imports from the Middle East on the Japanese economy. To assign the exogenous values in this scenario, two simulations are needed. The basic closure is changed in the first simulation by setting "ams" (the import-augmenting technical change) ${ }^{1}$ for Japan's crude oil imports from the Middle East, which is exogenous in the basic closure, as endogenous, and "qxs" (export sales) of crude oil from the Middle East to Japan, which is endogenous in the basic closure, as exogenous.

\footnotetext{
1 The theory of using "ams" is described in detail in Hertel, Walmsley, and Itakura (2001). Changes in the technical coefficient, of good $i$ exported from $r$ to $s$. To maintain the trade balance, the "ams," capture the impact of non-tariff measures on the price of imports from a particular exporter. Thus, a change in "ams" ensures a change in the effective domestic price product of the observed price and the quantity is adjusted to be equal to the product of the effective price and the quantity.
} 


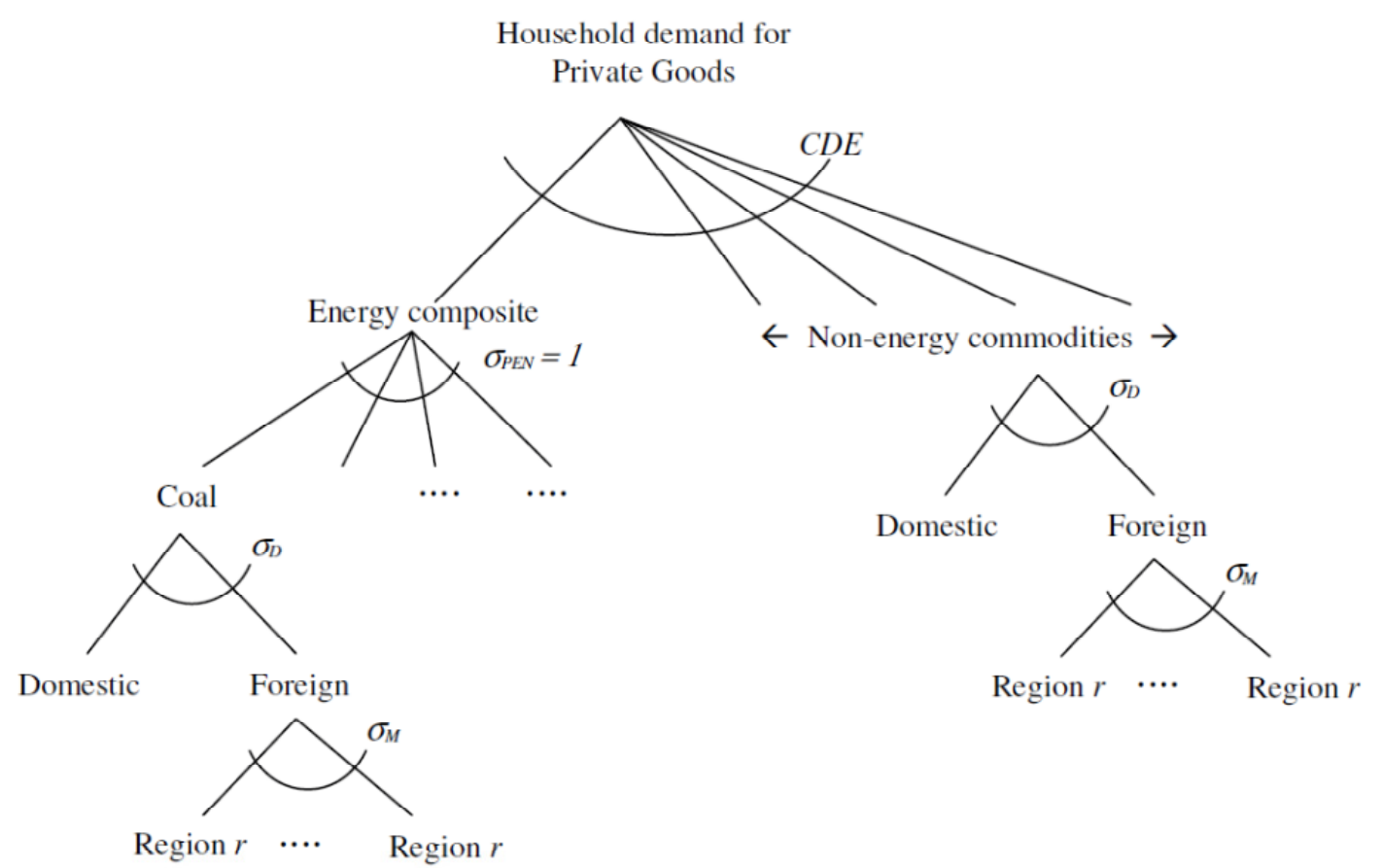

Figure 4. Private consumption structure of the GTAP-E model. Source: Burniaux and Truong (2002), Figure 19, p. 38.

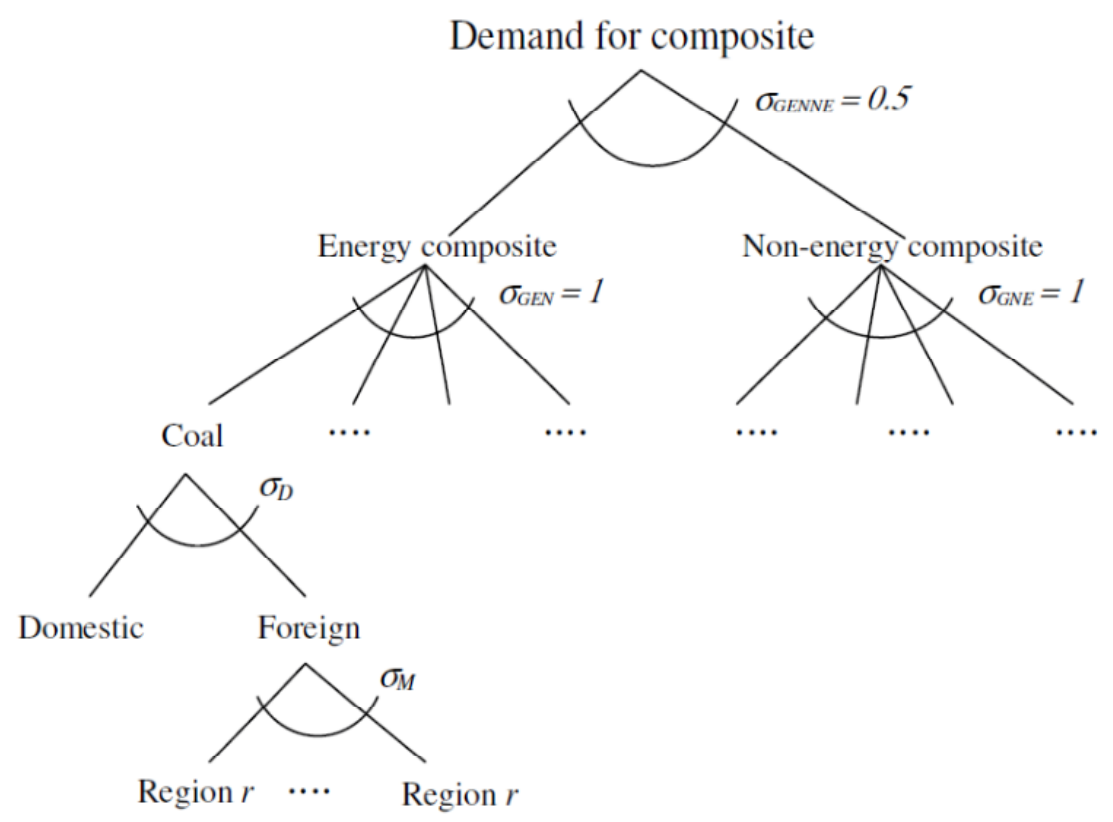

Figure 5. Government consumption structure of the GTAP-E model. Source: Burniaux and Truong (2002), Figure 18, p. 37.

These scenario considers that crude oil imports from the Middle East are reduced owing to some failure in transportation, and that there is a possibility of Japan increasing its crude oil supply from other regions. Considering these conditions, the exogenous values are set to $-25 \%$. To concentrate on the analysis of the impact in Japan, the exogenous values are applied only to Japanese crude oil imports from the Middle East. Japan also imports petroleum and coal products, and gas from the Middle East, but, here, we focus on only the decrease in crude oil imports. 
By applying the exogenous values to "qxs" in the first simulation, the rate of change in "ams" can be obtained. In the second simulation, which uses the basic closure, by using the rates at which "ams" decreased (taken from the first simulation) as exogenous values, the impact of a $25 \%$ decrease in Japanese crude oil imports from the Middle East on the Japanese economy can be estimated.

With regard to the investment allocation in the simulation, two options are possible in the GTAP and GTAP-E models. When RORDELTA (the binary coefficient used to switch the mechanism of allocating investment funds $)=1$, investment funds are allocated across regions to equate the changes in the expected rates of return. When RORDELTA $=0$, investment funds are allocated across regions to maintain the existing composition of capital stocks. Considering that the analysis period of this study is more towards the medium to long-term than the short-term, the option that investment funds are allocated across regions to equate the changes in the expected rates of return $($ RORDELTA $=1)$ is adopted.

\section{Methodology for Incorporating the Capital Accumulation Effects}

The GTAP and the GTAP-E models, which were originally developed for static analyses, do not analyze the dynamic process in which new investments use savings from the increase in income, or that in which an additional increase in income is achieved by the accumulated capital. However, they have the option to use an analysis that implements the effect of capital accumulation explained in GTAP Technical Paper No. 7.

As shown in Figure 6, when a change (in this case, positive) occurs, the production function YY and the savings function SS shift upward. In the short-term analysis, the capital used remains the same, and production increases to $\mathrm{Y}^{\prime}$. However, in the long-term, part of the income increase is directed to savings. Capital stock increases to $\mathrm{K}^{\prime \prime}$ by investment, and production increases to $\mathrm{Y}$. The analysis incorporating the capital accumulation effects tries to implement this movement of change in capital stock in the GTAP and GTAP-E models.

In this study, in which a decrease in income occurs, both the static analysis and the analysis incorporating the capital accumulation effects (with the fixed savings rate) are used.

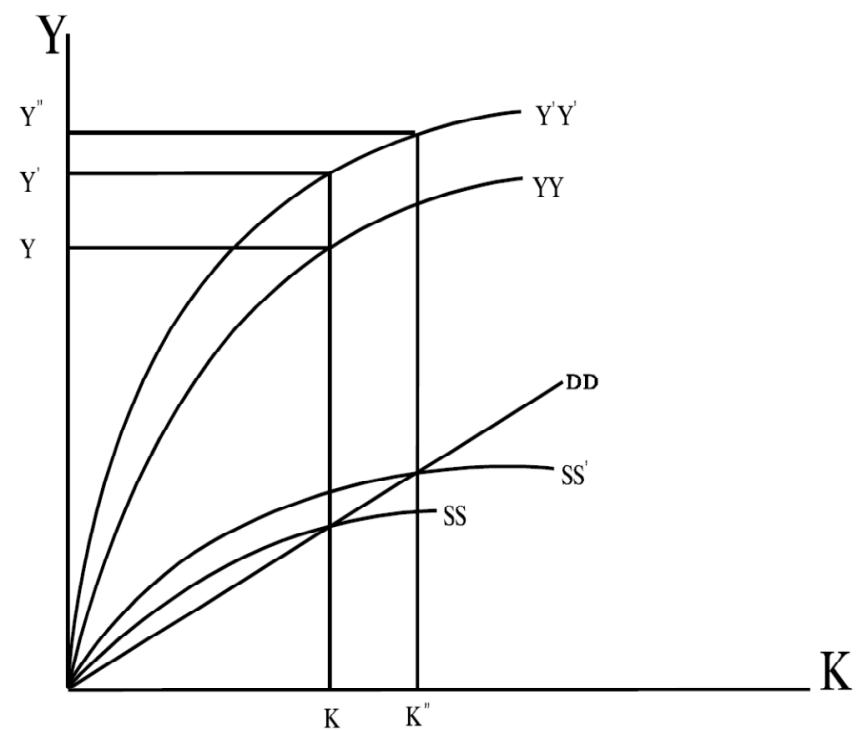

Figure 6. Short- and long-term effects of an income shock. Source: Francois, Mcdonald, and Nordström (1996), Figure 1, p. 3. 


\section{Aggregation of Regions and Sectors}

Considering the structure of Japanese crude oil imports, the regional aggregation in this study is set to 15 regions, as shown in Table 8. Regarding sectoral aggregation, it consists of 28 sectors, as shown in Table 9.

Table 8

Regional Disaggregation

\begin{tabular}{|c|c|c|c|}
\hline No. & Code & Region description & Comprising GTAP 9 countries/regions \\
\hline 1 & ANZ & Oceania & Australia, New Zealand, Rest of Oceania \\
\hline 2 & JPN & Japan & Japan \\
\hline 3 & $\mathrm{CHN}$ & China & China, Hong Kong \\
\hline 4 & KOR & Korea & Korea \\
\hline 5 & AEEx & $\begin{array}{l}\text { ASEAN Net Energy } \\
\text { Exporters }\end{array}$ & Brunei Darusslam, Indonesia, Malaysia, Viet Nam \\
\hline 6 & OASN & $\begin{array}{l}\text { Other ASEAN } \\
\text { countries }\end{array}$ & $\begin{array}{l}\text { Cambodia, Lao People's Democratic Republic, Philippines, Singapore, Thailand, } \\
\text { Rest of Southeast Asia }\end{array}$ \\
\hline 7 & ASA & Other Asian countries & $\begin{array}{l}\text { Mongolia, Taiwan, Rest of East Asia, Bangladesh, Nepal, Pakistan, Sri Lanka, } \\
\text { Rest of South Asia }\end{array}$ \\
\hline 8 & IND & India & India \\
\hline 9 & USA & United States & United States of America \\
\hline 10 & LTN & Latin America & $\begin{array}{l}\text { Mexico, Argentina, Bolivia, Brazil, Chile, Colombia, Ecuador, Paraguay, Peru, } \\
\text { Uruguay, Venezuela, Rest of South America, Costa Rica, Guatemala, Honduras, } \\
\text { Nicaragua, Panama, El Salvador, Rest of Central America, Dominican Republic, } \\
\text { Jamaica, Puerto Rico, Trinidad and Tobago, Caribbean }\end{array}$ \\
\hline 11 & EU28 & EU28 & $\begin{array}{l}\text { Austria, Belgium, Cyprus, Czech Republic, Denmark, Estonia, Finland, France, } \\
\text { Germany, Greece, Hungary, Ireland, Italy, Latvia, Lithuania, Luxembourg, Malta, } \\
\text { Netherlands, Poland, Portugal, Slovakia, Slovenia, Spain, Sweden, United } \\
\text { Kingdom, Bulgaria, Croatia, Romania }\end{array}$ \\
\hline 12 & EEFSU & $\begin{array}{l}\text { Eastern Europe and } \\
\text { FSU }\end{array}$ & $\begin{array}{l}\text { Albania, Belarus, Russian Federation, Ukraine, Rest of Eastern Europe, Rest of } \\
\text { Europe, Kazakhstan, Kyrgyzstan, Rest of the FSU, Armenia, Azerbaijan, Georgia }\end{array}$ \\
\hline 13 & MEC & Middle East & $\begin{array}{l}\text { Bahrain, Islamic Republic of Iran, Israel, Jordan, Kuwait, Oman, Qatar, Saudi } \\
\text { Arabia, United Arab Emirates, Rest of Western Asia }\end{array}$ \\
\hline 14 & AFR & Africa & $\begin{array}{l}\text { Egypt, Morocco, Tunisia, Rest of North Africa, Benin, Burkina Faso, Cameroon, } \\
\text { Cote d'Ivoire, Ghana, Guinea, Nigeria, Senegal, Togo, Rest of Western Africa, } \\
\text { Central Africa, South Central Africa, Ethiopia, Kenya, Madagascar, Malawi, } \\
\text { Mauritius, Mozambique, Rwanda, Tanzania, Uganda, Zambia, Zimbabwe, Rest of } \\
\text { Eastern Africa, Botswana, Namibia, South Africa, Rest of South African Customs } \\
\text { Union }\end{array}$ \\
\hline 15 & ROW & Rest of the World & $\begin{array}{l}\text { Canada, Rest of North America, Switzerland, Norway, Turkey, Rest of EFTA, } \\
\text { Rest of the World }\end{array}$ \\
\hline
\end{tabular}

Source: author.

Table 9

Sectoral Disaggregation

\begin{tabular}{|l|l|l|l|}
\hline No. & Code & Sector description & Comprising GTAP 9 sectors \\
\hline 1 & AGR & Agriculture & $\begin{array}{l}\text { Paddy rice, wheat, cereal grains nec }{ }^{*}, \text { vegetables, fruit, nuts, oil seeds, sugarcane, } \\
\text { sugar beet, plant-based fibers, crops nec, bovine cattle, sheep and goats, horses, } \\
\text { animal products nec, raw milk, wool, silk-worm cocoons, forestry, fishing }\end{array}$ \\
\hline 2 & Coal & Coal & Coal \\
\hline 3 & Oil & Oil & Oil \\
\hline 4 & Gas & Natural gas extraction & Gas, gas manufacture, distribution \\
\hline 5 & Oil_Pcts & $\begin{array}{l}\text { Petroleum, coal } \\
\text { products }\end{array}$ & Petroleum, coal products \\
\hline 6 & Electricity & Electricity & Electricity \\
\hline
\end{tabular}


Table 9 continued

\begin{tabular}{|c|c|c|c|}
\hline No. & Code & Sector description & Comprising GTAP 9 sectors \\
\hline 7 & OMN & Minerals nec & Minerals nec \\
\hline 8 & PFD & Food processing & $\begin{array}{l}\text { Bovine meat products, meat products nec, vegetable oils and fats, dairy products, } \\
\text { processed rice, sugar, food products nec, beverages and tobacco products }\end{array}$ \\
\hline 9 & TXL & Textiles & Textiles, wearing apparel \\
\hline 10 & CRP & $\begin{array}{l}\text { Chemical, rubber, } \\
\text { plastic products }\end{array}$ & Chemical, rubber, plastic products \\
\hline 11 & NMM & Mineral products nec & Mineral products nec \\
\hline 12 & I_S & Ferrous metals & Ferrous metals \\
\hline 13 & NFM & Metals nec & Metals nec \\
\hline 14 & FMP & Metal products & Metal products \\
\hline 15 & MVH & $\begin{array}{l}\text { Motor vehicles and } \\
\text { parts }\end{array}$ & Motor vehicles and parts \\
\hline 16 & OTN & $\begin{array}{l}\text { Transport equipment } \\
\text { nec }\end{array}$ & Transport equipment nec \\
\hline 17 & ELE & Electronic equipment & Electronic equipment \\
\hline 18 & OME & $\begin{array}{l}\text { Machinery and } \\
\text { equipment nec }\end{array}$ & Machinery and equipment nec \\
\hline 19 & OMF & Manufactures nec & Leather products, wood products, paper products, publishing, manufactures nec \\
\hline 20 & $\mathrm{CNS}$ & Construction & Construction \\
\hline 21 & TRD & Trade & Trade \\
\hline 22 & OTP & Transport nec & Transport nec \\
\hline 23 & WTP & Water transport & Water transport \\
\hline 24 & ATP & Air transport & Air transport \\
\hline 25 & $\mathrm{CMN}$ & Communication & Communication \\
\hline 26 & OFR & Financial services & Financial services nec, insurance \\
\hline 27 & OSP & Other services & Water, business services nec, recreational and other services, dwellings \\
\hline 28 & OSG & Public services & Public administration, defense, education, health \\
\hline
\end{tabular}

Source: author.

Note. * Not elsewhere classified.

\section{Discussion by Static Analysis}

\section{Macroeconomic Changes}

In this section, the simulation results of the GTAP and GTAP-E models are discussed, given a $25 \%$ decrease in crude oil imports from the Middle East to Japan, based on a static analysis. Table 10 and Table 11 show the simulation results of the macroeconomic changes, ${ }^{2}$ in percentages and in million USD, respectively.

The simulation results for the percentage change in Japan's real GDP are $-0.53 \%$ for the GTAP model and $-0.59 \%$ for the GTAP-E model. The results of the percentage change in Japan's exports are $+5.04 \%$ for the GTAP model and $+4.43 \%$ for the GTAP-E model. ${ }^{3}$ Although the difference between these results for real GDP

\footnotetext{
${ }^{2}$ The simulation results for the percentage change in Japan's "qiwreg" (index for macro-level imports) are $0.0 \%$ for the GTAP model and $-1.25 \%$ for the GTAP-E model. "Qiwreg" is based on the cost, insurance, and freight (CIF) price, which does not reflect the change caused by the change in "ams." On the other hand, the simulation results of "qim" (imports by industry) described in "Changes in Japanese imports" below are based on the market price, which does reflect the change caused by the change in "ams." Because the change in price caused by the change in "ams" is important in this study and the "qiw" simulation results by industry are not shown in the values, the import results are analyzed in "Changes in Japanese imports" below. Apart from crude oil, the results of the Japanese "piw" (world price of composite imports) and "pim" (market price of composite imports) are the same.

3 With regard to exports, "qxw" (aggregate exports, FOB weights) is used for both the macro-level and industry analyses. The sums of the Japanese "qxw" and "qxwreg" are almost the same.
} 
caused by the difference of the production structure of the two models is relatively small, the simulation results by industry and by commodity, especially with regard to energy goods, show different tendencies, as described in the following sections.

With regard to the simulation results for the percentage change in real GDP in other regions, real GDP increases slightly in regions that include energy exporters, such as AEEX (ASEAN Net Energy Exporters) and EEFSU (Eastern Europe and FSU).

Table 10

Macroeconomic Changes, by Static Analysis, Caused by a 25\% Decrease in Japan's Crude Oil Imports From the Middle East (Percentage)

\begin{tabular}{|c|r|r|r|r|}
\hline & \multicolumn{2}{|c|}{ Change in GDP } & \multicolumn{2}{c|}{ Change in Export } \\
\cline { 2 - 5 } & GTAP model & GTAP-E model & GTAP model & GTAP-E model \\
\hline ANZ & 0.00 & 0.00 & -0.12 & -0.30 \\
\hline JPN & -0.53 & -0.59 & 5.04 & 4.43 \\
\hline CHN & 0.01 & 0.01 & 0.00 & -0.12 \\
\hline KOR & 0.00 & 0.01 & 0.28 & 0.07 \\
\hline AEEx & 0.03 & 0.03 & -0.06 & -0.33 \\
\hline OASN & 0.01 & 0.01 & 0.09 & -0.02 \\
\hline ASA & 0.00 & 0.00 & 0.02 & -0.09 \\
\hline IND & 0.01 & 0.01 & 0.17 & -0.04 \\
\hline USA & 0.00 & 0.00 & -0.32 & -0.41 \\
\hline LTN & 0.01 & 0.01 & -0.36 & -0.30 \\
\hline EU28 & -0.01 & -0.01 & -0.11 & -0.17 \\
\hline EEFSU & 0.05 & 0.03 & -0.52 & -0.27 \\
\hline MEC & 0.01 & 0.00 & -0.18 & -0.02 \\
\hline AFR & 0.01 & 0.01 & -0.31 & -0.13 \\
\hline ROW & 0.00 & 0.00 & -0.24 & -0.18 \\
\hline & & & & \\
\hline
\end{tabular}

Source: author.

Table 11

Macroeconomic Changes, by Static Analysis, Caused by a 25\% Decrease in Japan's Crude Oil Imports From the Middle East (Millions, USD)

\begin{tabular}{|c|r|r|r|r|r|r|}
\hline & \multicolumn{2}{|c|}{ Change in GDP } & \multicolumn{2}{c|}{ Change in Export } & \multicolumn{2}{c|}{ Change in EV } \\
\cline { 2 - 7 } & GTAP model & $\begin{array}{c}\text { GTAP-E } \\
\text { model }\end{array}$ & GTAP model & $\begin{array}{c}\text { GTAP-E } \\
\text { model }\end{array}$ & GTAP model & $\begin{array}{c}\text { GTAP-E } \\
\text { model }\end{array}$ \\
\hline ANZ & -27 & 57 & -415 & $-1,053$ & -445 & 186 \\
\hline JPN & $-31,575$ & $-34,713$ & 47,520 & 41,784 & $-40,663$ & $-41,262$ \\
\hline CHN & 883 & 972 & 1 & $-2,549$ & -743 & 1,177 \\
\hline KOR & -51 & 106 & 1,733 & 419 & -921 & 12 \\
\hline AEEx & 363 & 407 & -353 & $-1,829$ & 2,118 & 2,235 \\
\hline OASN & 78 & 104 & 572 & -149 & -213 & 302 \\
\hline ASA & -22 & 23 & 80 & -444 & -466 & 204 \\
\hline IND & 125 & 250 & 621 & -160 & -656 & 523 \\
\hline USA & -157 & 161 & $-6,098$ & $-7,609$ & $-1,872$ & 1,734 \\
\hline LTN & 473 & 381 & $-4,319$ & $-3,619$ & 2,015 & 1,149 \\
\hline EU28 & $-2,638$ & -918 & $-7,402$ & $-11,616$ & $-6,970$ & -858 \\
\hline EEFSU & 1,303 & 704 & $-4,454$ & $-2,279$ & 7,639 & 2,923 \\
\hline MEC & 330 & -16 & $-2,264$ & -232 & 5,139 & $-2,494$ \\
\hline AFR & 281 & 140 & $-2,047$ & -817 & 4,194 & 1,520 \\
\hline ROW & -17 & 70 & $-2,853$ & $-2,117$ & 1,131 & 355 \\
\hline
\end{tabular}

Source: author. 


\section{Changes in Japanese Industrial Output}

Figures 7 and 8 show the simulation results of Japan's industrial output with the GTAP and GTAP-E models. The results of both models show the same tendency, although the negative impacts are stronger in the GTAP-E model. Among all sectors, the reduction rate is especially large in Oil_Pcts (petroleum and coal products), attaining $-7.3 \%$ in the GTAP model and $-11.0 \%$ in the GTAP-E model. ${ }^{4}$ The largest change in terms of millions USD is again observed in Oil_Pcts. The decrease in this sector attains USD 21.1 billion according to the GTAP model, and USD 31.7 billion according to the GTAP-E model. After Oil_Pcts, the construction sector is the most severely affected by the decrease in crude oil imports in Japan. The industrial output of the construction sector decreases by $2.6 \%$ according to the GTAP model, and by $3.3 \%$ according to the GTAP-E model.

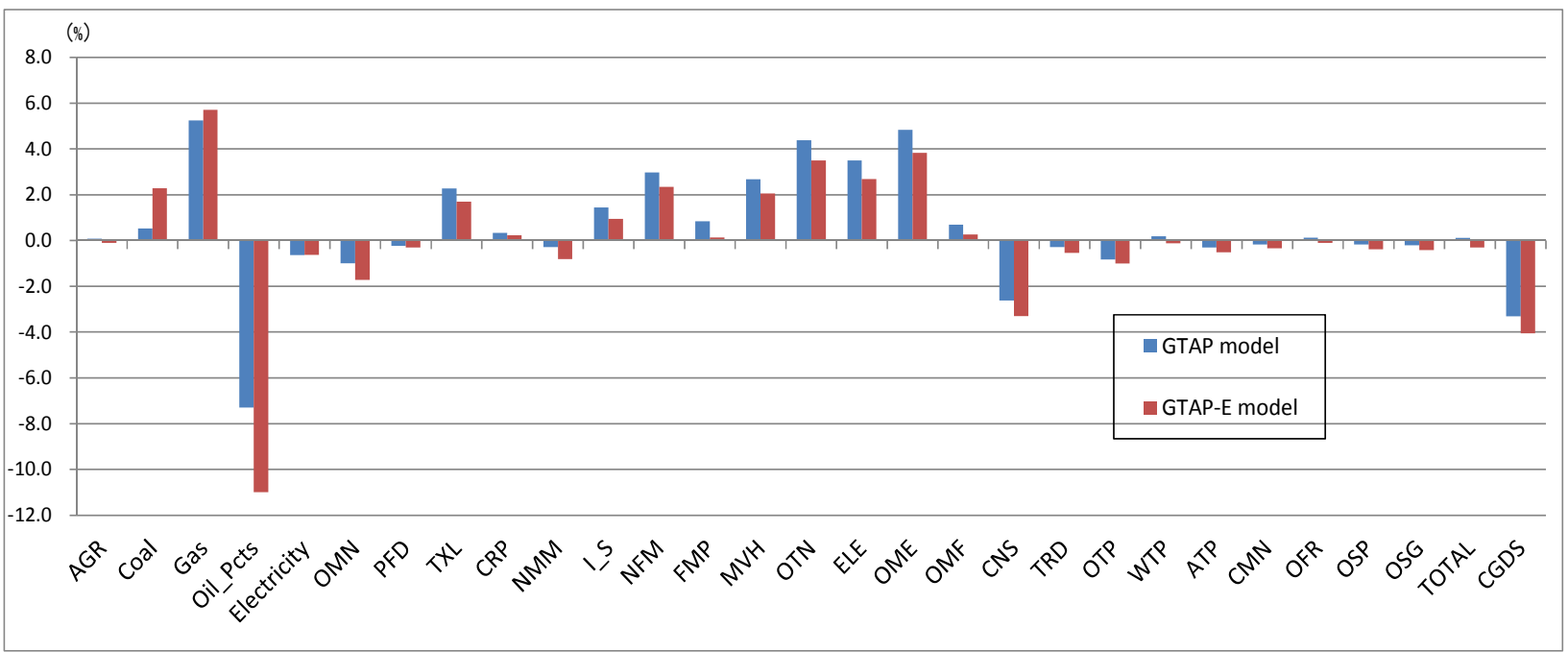

Figure 7. Impacts on Japan's industrial output, by static analysis, caused by a $25 \%$ decrease in Japan's crude oil imports from the Middle East (percentage). Source: author.

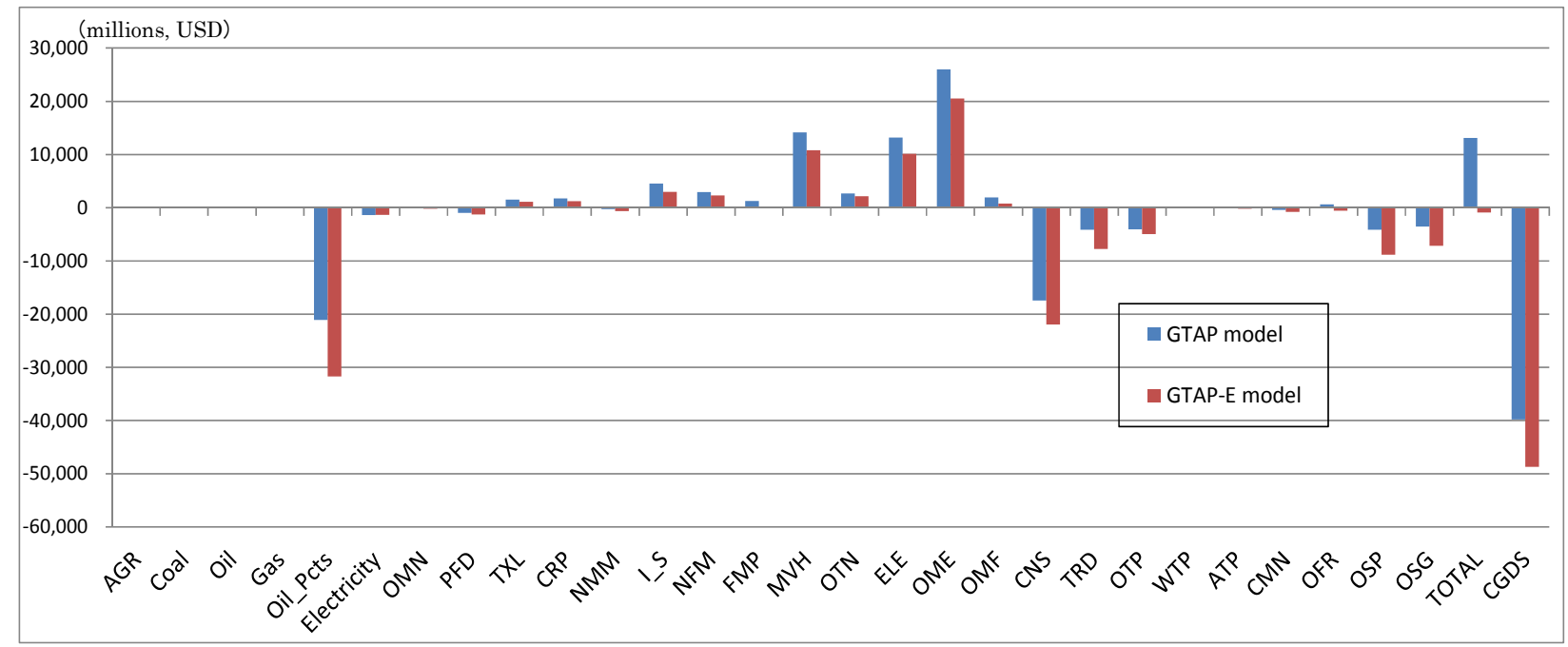

Figure 8. Impacts on Japan's industrial output, by static analysis, caused by a $25 \%$ decrease in Japan's crude oil imports from the Middle East (millions, USD). Source: author.

\footnotetext{
${ }^{4}$ In Figure 7, the results for the oil sector are not shown because it increases by more than by $30 \%$ in the GTAP-E model, even though its industrial output is small.
} 
Because the capital stock in Japan is not damaged in this scenario, Japanese industrial sectors would try to use their production capacity. As a result, industrial outputs increase in some sectors. Because of the crude oil supply shortage, the use of other primary energy goods, such as coal and gas, would increase. In non-energy-intensive industries, such as OTN (transport equipment nec), ELE (electronic equipment), and OME (machinery and equipment nec), the positive percentage change is relatively high. When the changes are evaluated in terms of millions USD, the greatest increases are shown in OME, which attains USD 26 billion according to the GTAP model, and USD 20.5 billion according to the GTAP-E model.

With regard to the overall balance of industrial output, the simulation result of the GTAP model, in which the negative effect is less than that of the GTAP-E model, becomes slightly positive. However, in the simulation result of the GTAP-E model, the negative impacts surpass the positive ones, and the overall balance of industrial output becomes negative.

Figures 7 and 8 also show the simulation results of the qo ("cgds", r), the output of the capital goods sector, which is equal to qcgds(r), a variable denoting gross investment. The negative effect in the simulation results of gross investment is noteworthy. It decreases by $3.3 \%$ according to the GTAP model, and by $4.1 \%$ according to the GTAP-E model, while the sign is positive in all other regions.

\section{Changes in Japanese Private Consumption}

The simulation results of both models show a similar tendency. Evaluated in terms of millions of USD, a large decrease is observed in the private consumption of Oil_Pcts (petroleum and coal products), PFD (food processing), and service commodities such as TRD (trade), OTP (transport nec), and OSP (other services). The largest percentage change is observed in crude oil, although private consumption in this case is almost zero.

In the simulation results of private consumption, shown in Figures 9 and 10, negative impacts are marginally stronger in the GTAP model. Total private consumption decreases by $0.9 \%$ according to the GTAP model, and by $0.8 \%$ according to the GTAP-E model. The reason for this difference lies in the price change difference, as described below. Table 12 shows the simulation results for Japan's private consumption of energy goods and non-energy goods.

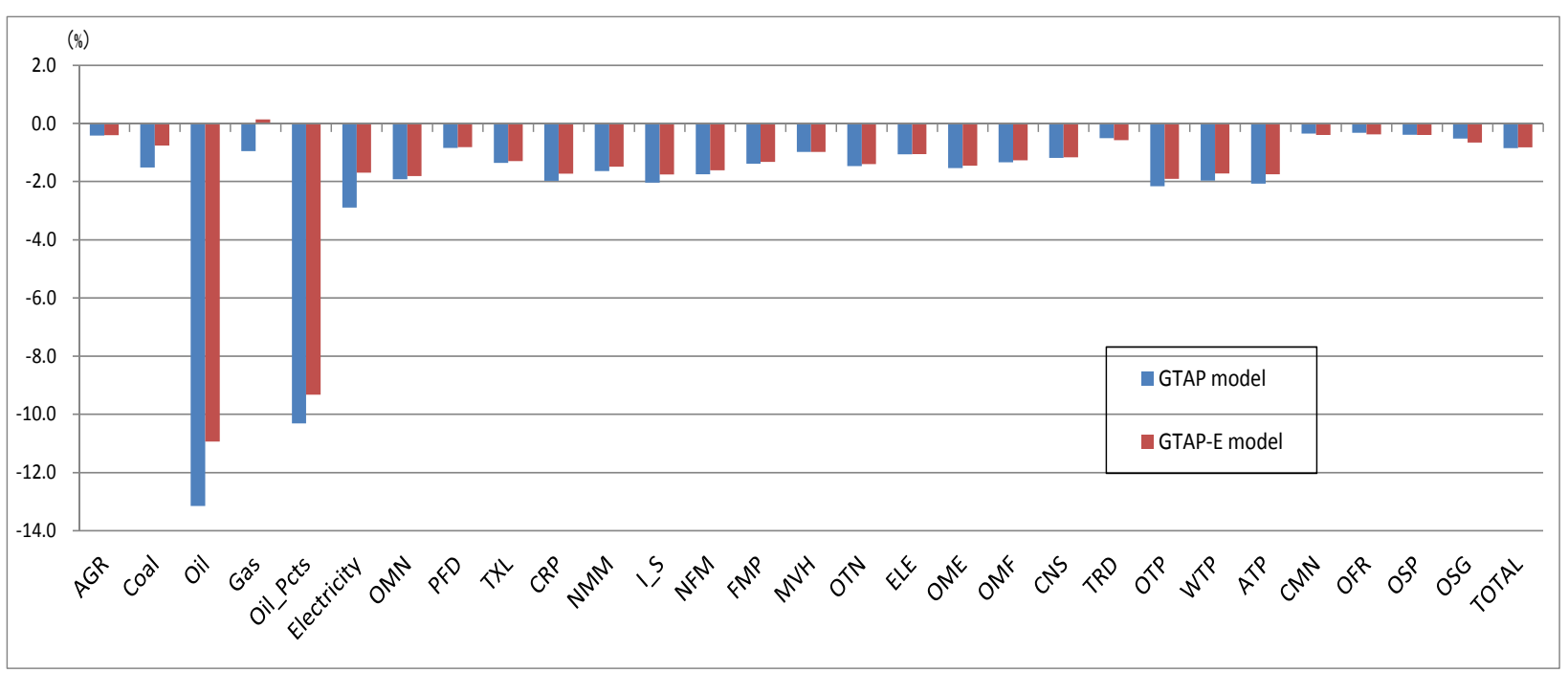

Figure 9. Impacts on Japan's private consumption, by static analysis, caused by a $25 \%$ decrease in Japan's crude oil imports from the Middle East (percentage). Source: author. 


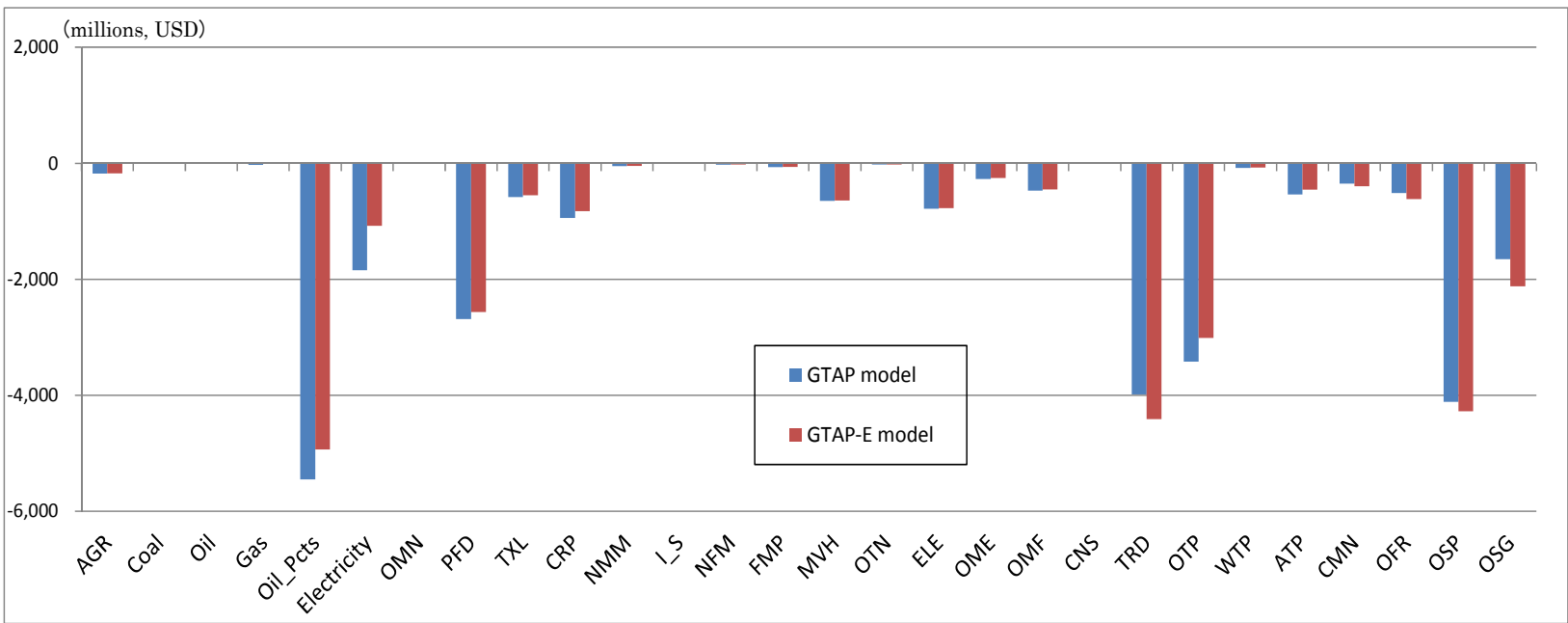

Figure 10. Impacts on Japan's private consumption, by static analysis, caused by a 25\% decrease in Japan's crude oil imports from the Middle East (millions, USD). Source: author.

Table 12

Japan's Private Consumption Changes in Energy Goods and Non-energy Goods, by Static Analysis, Caused by a 25\% Decrease in Crude Oil Imports From the Middle East (Millions, USD)

\begin{tabular}{llll}
\hline & Energy goods & Non energy goods & TOTAL \\
\hline GTAP model & -7.323 & -21.367 & -28.689 \\
GTAP e model & -6.005 & -21.730 & -27.735 \\
\hline
\end{tabular}

Source: author.

With regard to energy goods, the decrease in the GTAP-E model is less serious than that in the GTAP model, because the increase in the price of energy goods is higher in the GTAP model. Though there is little difference in the change in non-energy goods between the two models, the change in total private consumption becomes more negative in the GTAP model, owing to the decrease in energy commodities.

\section{Changes in Japanese Supply Price}

Figure 11 shows the simulation results of changes to Japan's supply price with the GTAP and GTAP-E models (in percentages).

Though both models show similar results in terms of the supply price of non-energy goods, those concerning energy goods, especially crude oil, show a marked difference. The crude oil price increases by $14 \%$ according to the GTAP model. However, in the GTAP-E model, owing to the substitution structure in the capital-energy composite and in the energy composite, the increase is about $5 \%$, which is less than that in the GTAP model. Furthermore, for petroleum and coal products, there is a clear difference in the supply price in the results of the two models.

\section{Changes in Japanese Exports}

The simulation results of changes in Japan's exports for both models (in percentages) are shown in Figure 12..$^{5}$ As previously mentioned, the results of both models with regard to industrial output in each sector show

\footnotetext{
${ }^{5}$ In Figure 12, the results of the crude oil and gas sectors are not shown because they show greater changes than the other sectors do: crude oil exports decrease by $67.6 \%$ according to the GTAP model, and by $36.6 \%$ according to the GTAP-E model. Gas exports increase by $77.5 \%$ according to the GTAP model, and by $61.7 \%$ according to the GTAP-E model. However, the values of crude oil and gas exports are nearly zero.
} 
similar tendencies, although the negative impacts are stronger in the GTAP-E model. With regard to exports, the results of both models are similar in almost all industries, although the positive change in the GTAP model is slightly larger than that in the GTAP-E model, with the exception of petroleum and coal products. Because industrial outputs decrease in the GTAP model by less than they do in the GTAP-E model, petroleum and coal products are used more domestically than they are in the GTAP-E model. Therefore, exports of petroleum and coal products would decrease by more in the GTAP model than they would in the GTAP-E model. In both models, exports increase in non-energy-intensive goods, such as MVH (motor vehicles and parts), ELE (electronic equipment), and OME (machinery and equipment nec), in which industrial output tends to increase.

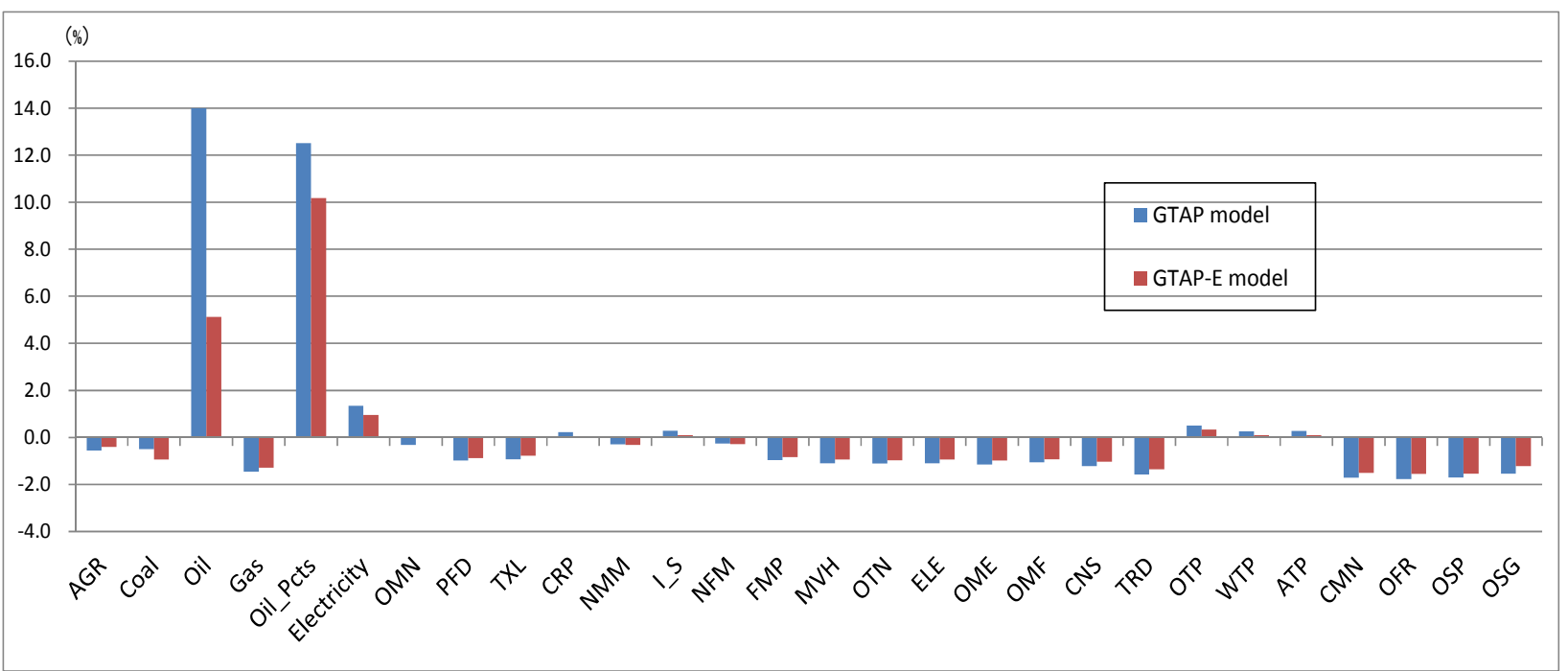

Figure 11. Impacts on Japan's supply price, by static analysis, caused by a 25\% decrease in Japan's crude oil imports from the Middle East (percentage). Source: author.

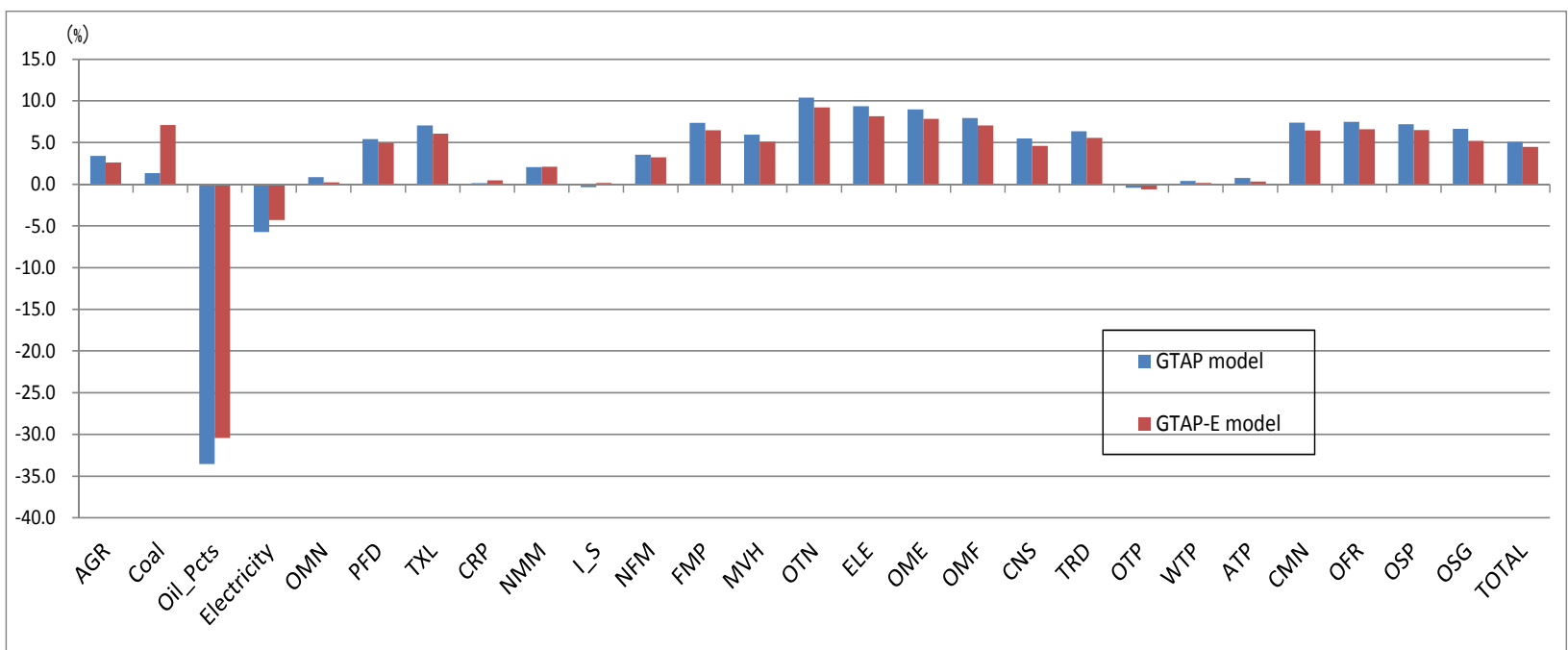

Figure 12. Impacts on Japan's exports, by static analysis, caused by a $25 \%$ decrease in Japan's crude oil imports from the Middle East (percentage). Source: author.

Figure 13 shows the simulation results of changes in Japanese exports, evaluated in millions USD. In both models, the positive impacts in non-energy-intensive goods overcome the negative impacts in petroleum and coal products. 


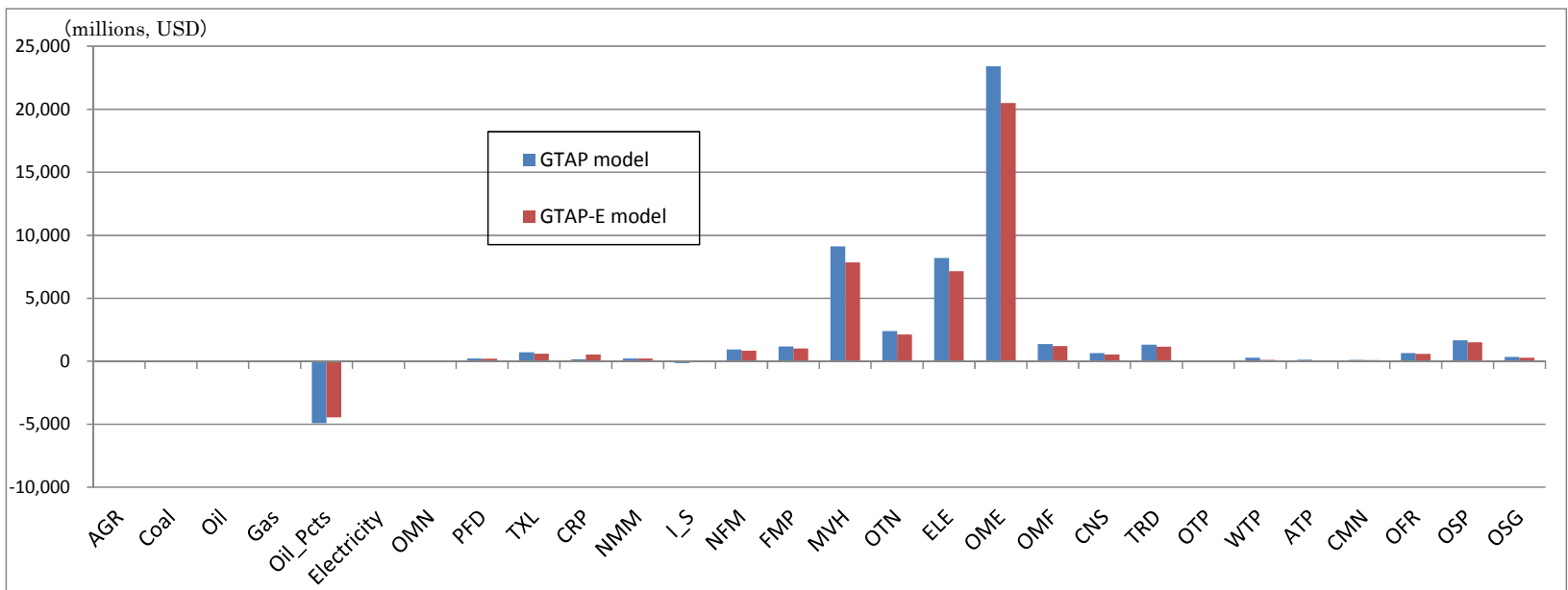

Figure 13. Impacts on Japan's exports by static analysis caused by a 25\% decrease in Japan's crude oil imports from the Middle East (millions, USD). Source: author.

\section{Changes in Japanese Imports}

Figure 14 shows the simulation results of changes in Japan's imports (market price weights), simulated by the GTAP and the GTAP-E models (in percentages). The difference between the simulation results of the GTAP model and the GTAP-E model is clear for energy goods, especially crude oil. When crude oil imports from the Middle East decrease according to the GTAP model, which does not have a structure for substitution between energy goods, Japan would try to increase its crude oil imports from other regions in order to secure its crude oil supply. However, according to the GTAP-E model, in which energy goods are treated as factors of production and there is a structure for substitution between energy goods, the substitution effects between crude oil and other energy goods take effect. Reflecting this difference in the structure of energy goods, the imports of crude oil decrease by more in the GTAP-E model than they do in the GTAP model.

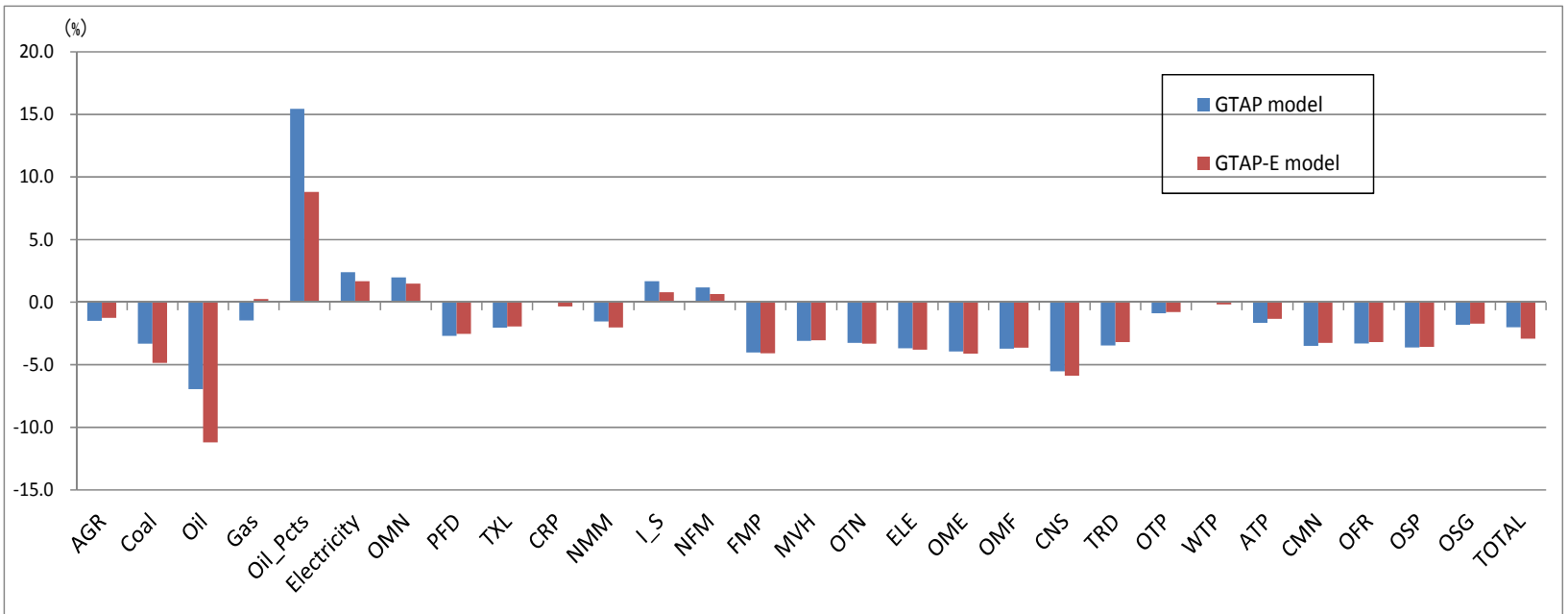

Figure 14. Impacts on Japan's imports, by static analysis, caused by a $25 \%$ decrease in Japan's crude oil imports from the Middle East (percentage). Source: author.

When crude oil imports from the Middle East decrease, Japan would also try to increase its imports of petroleum and coal products, which use crude oil as feedstock. ${ }^{6}$ However, in the GTAP-E model, which

${ }^{6}$ An increase in the imports of petroleum and coal products includes those from the Middle East. 
incorporates a substitution structure in the capital-energy composite and in the energy composite, imports of petroleum and coal products would not increase by as much as they do in the GTAP model.

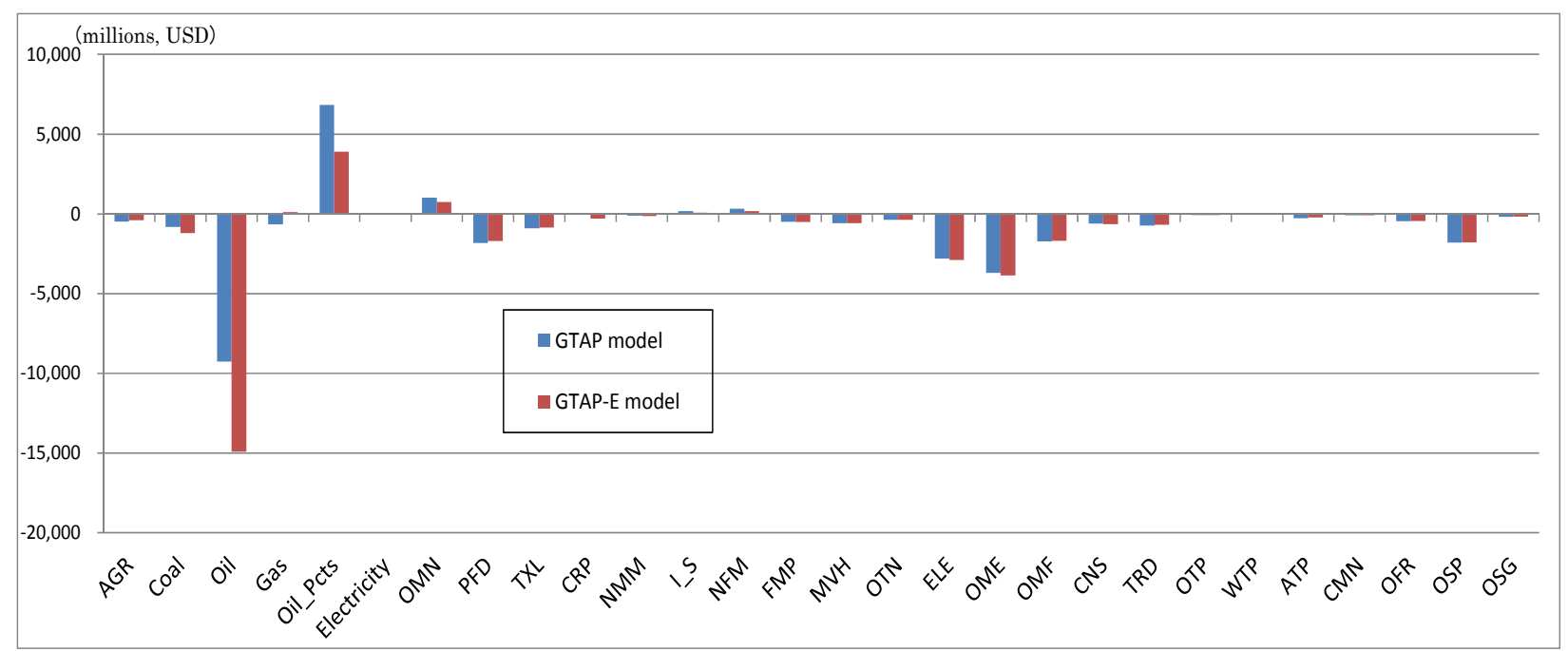

Figure 15. Impacts on Japan's imports, by static analysis, caused by a $25 \%$ decrease in Japan's crude oil imports from the Middle East (millions, USD). Source: author.

Figure 15 shows the simulation results for Japan's imports, evaluated in millions USD. Figures 14 and 15 show little difference in the change in imports between the two models for non-energy goods.

\section{Discussion of the Analysis Incorporating Capital Accumulation Effects}

\section{Macroeconomic Changes}

This section discusses the simulation results of the GTAP and GTAP-E models with regard to a $25 \%$ decrease in Japan's crude oil imports from the Middle East, incorporating capital accumulation effects. Tables 13 and 14 show the simulation results of macroeconomic changes, in percentages and in million USD, respectively.

The simulation results for the percentage changes in Japan's real GDP are $-1.04 \%$ for the GTAP model, and $-1.19 \%$ for the GTAP-E model. The difference between these results is a little larger than that of the static analysis, and becomes clearer with regard to exports. The percentage change in Japan's exports is almost $0.9 \%$ for the GTAP model and $-0.6 \%$ for the GTAP-E model. ${ }^{7}$

The simulation results for the percentage change in real GDP in other regions in the GTAP model are all positive, and increase by more than they do in other regions when energy exporters are included, such as AEEx (ASEAN Net Energy Exporters), EEFSU (Eastern Europe and FSU), MEC (Middle East), and AFR (Africa). In the results of the GTAP-E model, the negative effect on the Japanese real GDP increases, and in some regions, the sign of the percentage change of real GDP becomes negative because it is affected by the change in Japanese trade.

\footnotetext{
7 The simulation results for the percentage change in Japan's imports based on CIF weights are $0.6 \%$ for the GTAP model and $-0.46 \%$ for the GTAP-E model.
} 
Table 13

Macroeconomic Changes, Including Capital Accumulation Effects, Caused by a 25\% Decrease in Japan's Crude Oil Imports From the Middle East (Percentage)

\begin{tabular}{|c|r|r|r|r|}
\hline & \multicolumn{2}{|c|}{ Change in GDP } & \multicolumn{2}{c|}{ Change in Export } \\
\cline { 2 - 5 } & GTAP model & GTAP-E model & GTAP model & GTAP-E model \\
\hline ANZ & 0.01 & -0.04 & 0.10 & -0.10 \\
\hline JPN & -1.04 & -1.19 & 0.86 & -0.57 \\
\hline CHN & 0.03 & -0.01 & 0.03 & -0.02 \\
\hline KOR & 0.01 & -0.01 & 0.28 & 0.11 \\
\hline AEEx & 0.11 & 0.12 & 0.23 & 0.05 \\
\hline OASN & 0.06 & -0.01 & 0.25 & 0.09 \\
\hline ASA & 0.06 & 0.01 & 0.14 & 0.01 \\
\hline IND & 0.05 & 0.03 & 0.25 & 0.13 \\
\hline USA & 0.02 & 0.00 & 0.05 & 0.00 \\
\hline LTN & 0.09 & 0.01 & 0.00 & -0.01 \\
\hline EU28 & 0.03 & -0.01 & 0.05 & -0.01 \\
\hline EEFSU & 0.24 & 0.09 & -0.03 & 0.04 \\
\hline MEC & 0.25 & -0.05 & 0.12 & 0.01 \\
\hline AFR & 0.16 & 0.04 & -0.03 & 0.04 \\
\hline ROW & 0.07 & 0.01 & -0.03 & 0.00 \\
\hline
\end{tabular}

Source: author.

Table 14

Macroeconomic Changes, Including Capital Accumulation Effects, Caused by a 25\% Decrease in Japan's Crude Oil Imports From the Middle East (Millions, USD)

\begin{tabular}{|c|r|r|r|r|r|r|}
\hline & \multicolumn{2}{|c|}{ Change in GDP } & \multicolumn{2}{c|}{ Change in Export } & \multicolumn{2}{c|}{ Change in EV } \\
\hline & GTAP model & $\begin{array}{c}\text { GTAP-E } \\
\text { model }\end{array}$ & GTAP model & $\begin{array}{c}\text { GTAP-E } \\
\text { model }\end{array}$ & GTAP model & $\begin{array}{c}\text { GTAP-E } \\
\text { model }\end{array}$ \\
\hline ANZ & 101 & -587 & 351 & -363 & -813 & -712 \\
\hline JPN & $-61,227$ & $-70,185$ & 8,159 & $-5,338$ & $-50,674$ & $-53,390$ \\
\hline CHN & 2,461 & -465 & 724 & -521 & -502 & $-1,044$ \\
\hline KOR & 143 & -135 & 1,734 & 708 & -749 & -286 \\
\hline AEEx & 1,478 & 1,502 & 1,264 & 262 & 2,394 & 2,348 \\
\hline OASN & 591 & -50 & 1,644 & 630 & -123 & -146 \\
\hline ASA & 593 & 81 & 676 & 61 & -127 & 9 \\
\hline IND & 903 & 522 & 924 & 501 & 20 & 565 \\
\hline USA & 3,014 & 254 & 946 & 63 & $-1,522$ & -290 \\
\hline LTN & 5,643 & 420 & 24 & -118 & 4,740 & 261 \\
\hline EU28 & 4,746 & $-1,048$ & 3,271 & -723 & $-2,077$ & $-1,736$ \\
\hline EEFSU & 6,210 & 2,244 & -254 & 332 & 10,221 & 3,413 \\
\hline MEC & 6,372 & $-1,340$ & 1,564 & 68 & 8,639 & $-4,267$ \\
\hline AFR & 3,349 & 894 & -167 & 279 & 5,937 & 1,637 \\
\hline ROW & 2,541 & 264 & -311 & -46 & 2,624 & 214 \\
\hline
\end{tabular}

Source: author.

\section{Changes in Japanese Industrial Output}

Figures 16 and 17 show the impacts on Japan's industrial output, incorporating capital accumulation effects. The results show similar tendencies, although the negative impacts are stronger in the GTAP-E model.

Compared with the simulation results of the static analysis, the impact of the decrease in crude oil imports becomes more serious when capital accumulation effects are included. The reduction rate is especially large in the petroleum and coal products sector: $-7.8 \%$ according to the GTAP model, and $-11.3 \%$ according to the 
GTAP-E model. ${ }^{8}$ Although these changes are almost as large as those in the static analysis are, the impacts become more negative for non-energy goods (i.e., agriculture, manufacturing, and service sectors). With regard to the total balance of industrial output, the results of the GTAP model, in which the negative effect is less than that in the GTAP-E model, show a decrease of about USD 71 billion. In the GTAP-E model, the decrease is about USD 135 billion.

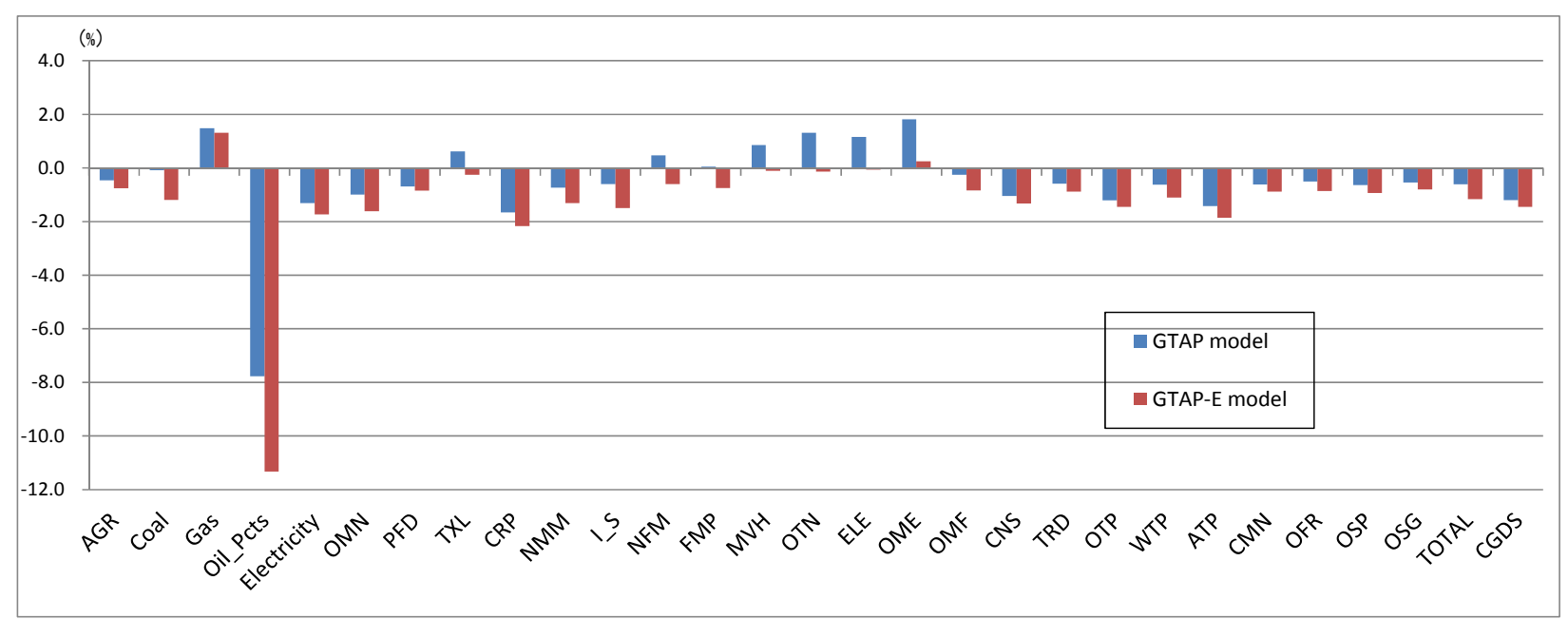

Figure 16. Impacts on Japan's industrial output, with capital accumulation effects, caused by a $25 \%$ decrease in Japan's crude oil imports from the Middle East (percentage). Source: author.

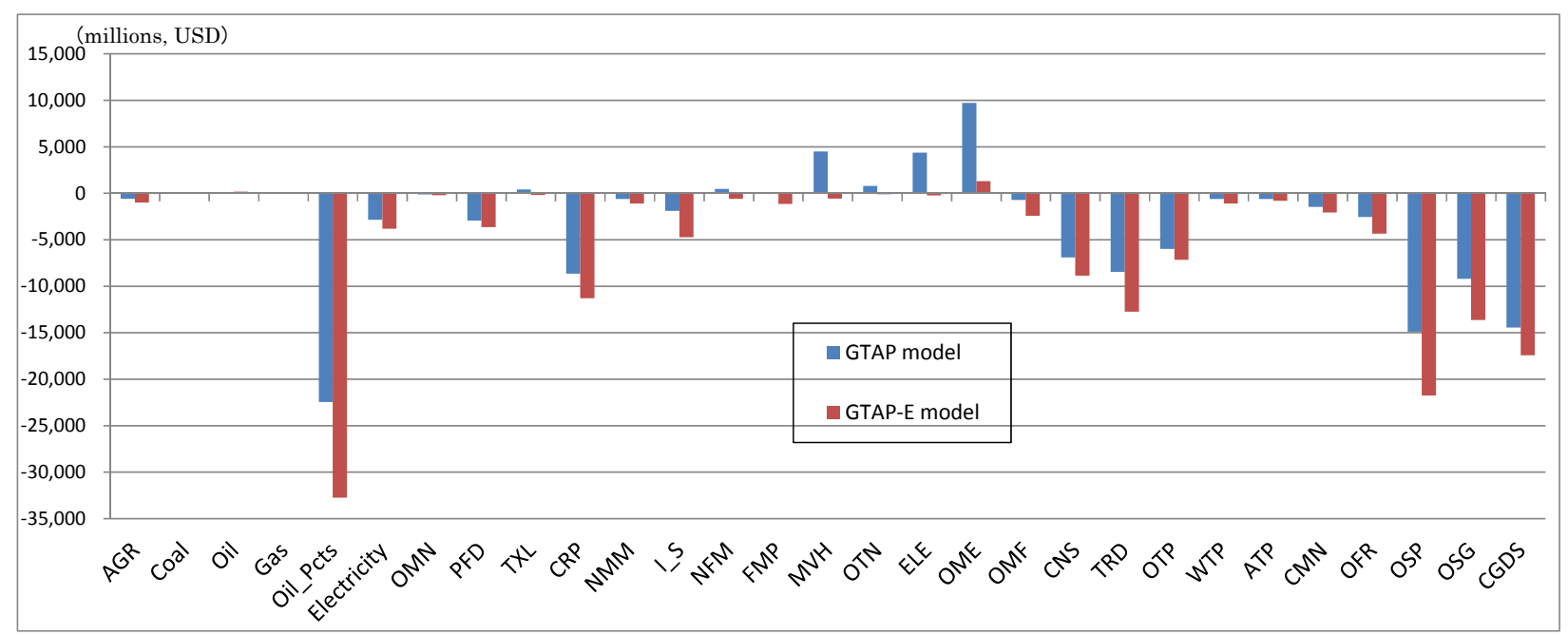

Figure 17. Impacts on Japan's industrial output, with capital accumulation effects, caused by a $25 \%$ decrease in Japan's crude oil imports from the Middle East (millions, USD). Source: author.

\section{Changes in Japanese Private Consumption}

Figures 18 and 19 show the impacts on Japan's private consumption, incorporating capital accumulation effects. The simulation results of both models are similar. As already seen in the static analysis results, a large decrease (in millions USD) is observed in the private consumption of Oil_Pcts (petroleum and coal products), PFD (food processing), and service commodities, such as TRD (trade), OTP (transport nec), and OSP (other services).

\footnotetext{
${ }^{8}$ In Figure 16, the result of the crude oil sector is not shown because it increases by more than $30 \%$ of the result of the GTAP-E model, although its industrial output is small.
} 


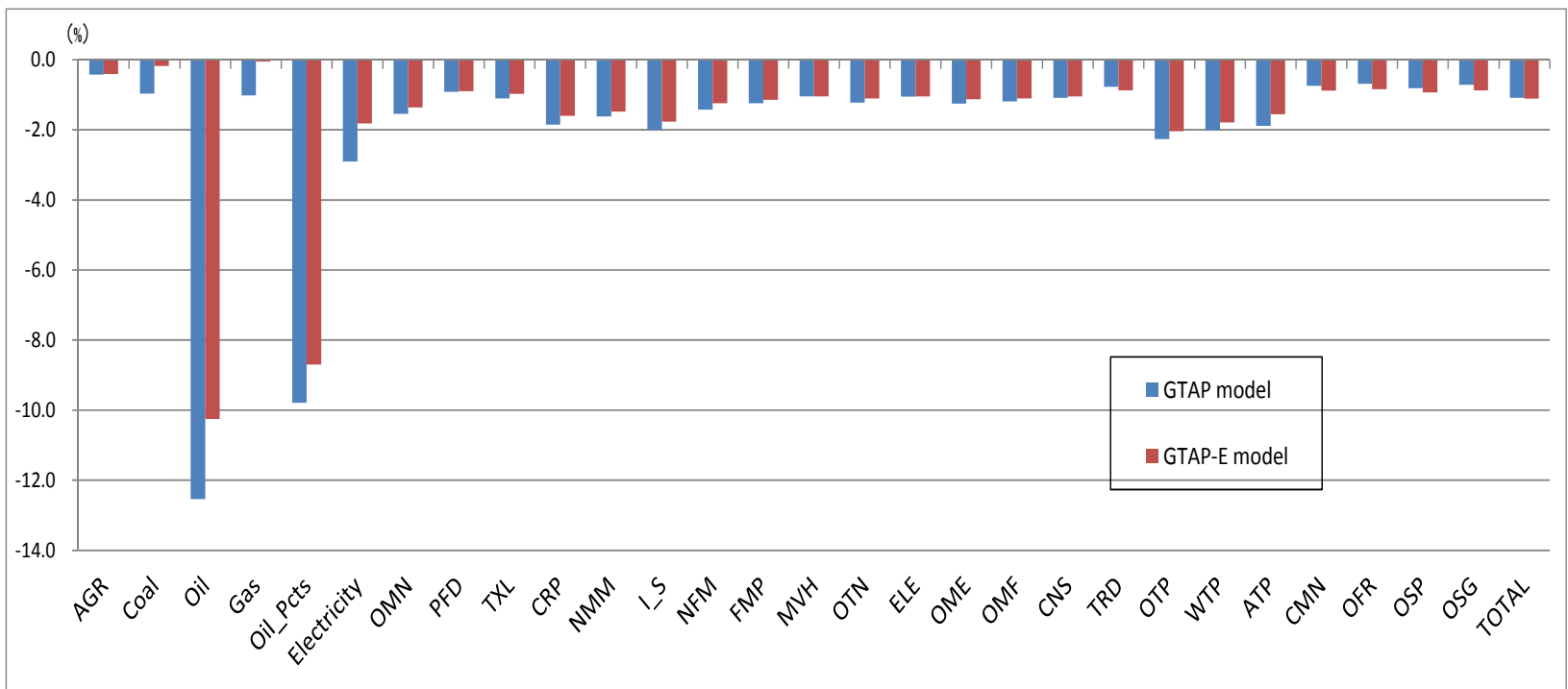

Figure 18. Impacts on Japan's private consumption, with capital accumulation effects, caused by a 25\% decrease in Japan's crude oil imports from the Middle East (percentage). Source: author.

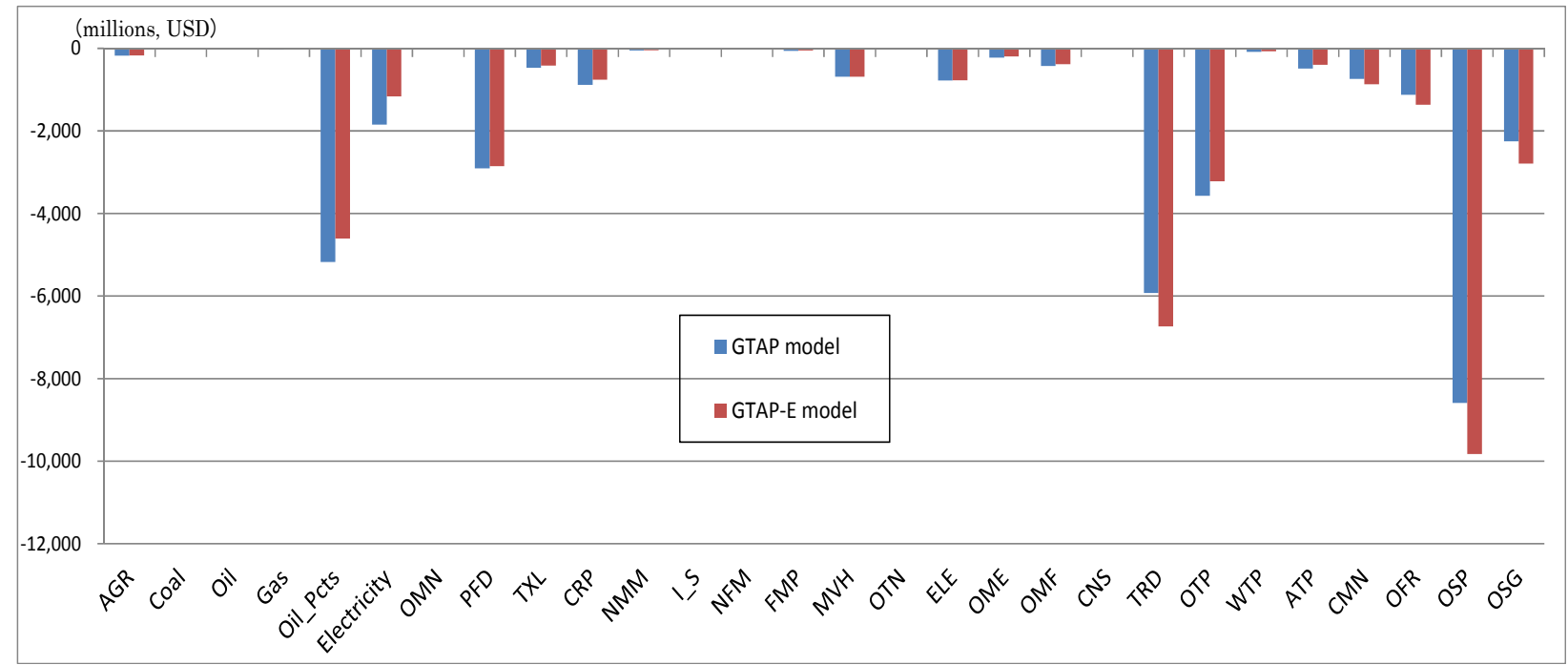

Figure 19. Impacts on Japan's private consumption, with capital accumulation effects, caused by a $25 \%$ decrease in Japan's crude oil imports from the Middle East (millions, USD). Source: author.

Total private consumption decreases by $1.1 \%$ in both models, and the negative impacts are slightly stronger in the GTAP-E model, in contrast to the results of the static analysis. Table 15 shows the simulation results for Japan's private consumption of energy goods and non-energy goods.

Table 15

Private Consumption Changes in Energy Goods and Non-energy Goods, With Capital Accumulation Effects, Caused by a 25\% Decrease in Japan's Crude Oil Imports From the Middle East (Millions, USD)

\begin{tabular}{llll}
\hline & Energy goods & Non-energy goods & Total \\
\hline GTAP model & $-7,053$ & $-29,441$ & $-36,494$ \\
GTAP-E model & $-5,765$ & $-31,646$ & $-37,411$ \\
\hline
\end{tabular}

Source: author. 
With regard to energy goods, the decrease in the simulation results of the GTAP-E model is less serious than that in the GTAP model, as in the case of the static analysis, because the price of energy goods increases by more in the GTAP model. However, the change in non-energy goods is more serious in the GTAP-E model than it is in the GTAP model. When capital accumulation effects are incorporated, the change in total private consumption becomes more negative in the GTAP-E model than it is in the GTAP model.

\section{Changes in Japanese Supply Price}

Figure 20 shows the simulation results of changes in Japan's supply price, incorporating capital accumulation effects (in percentages).

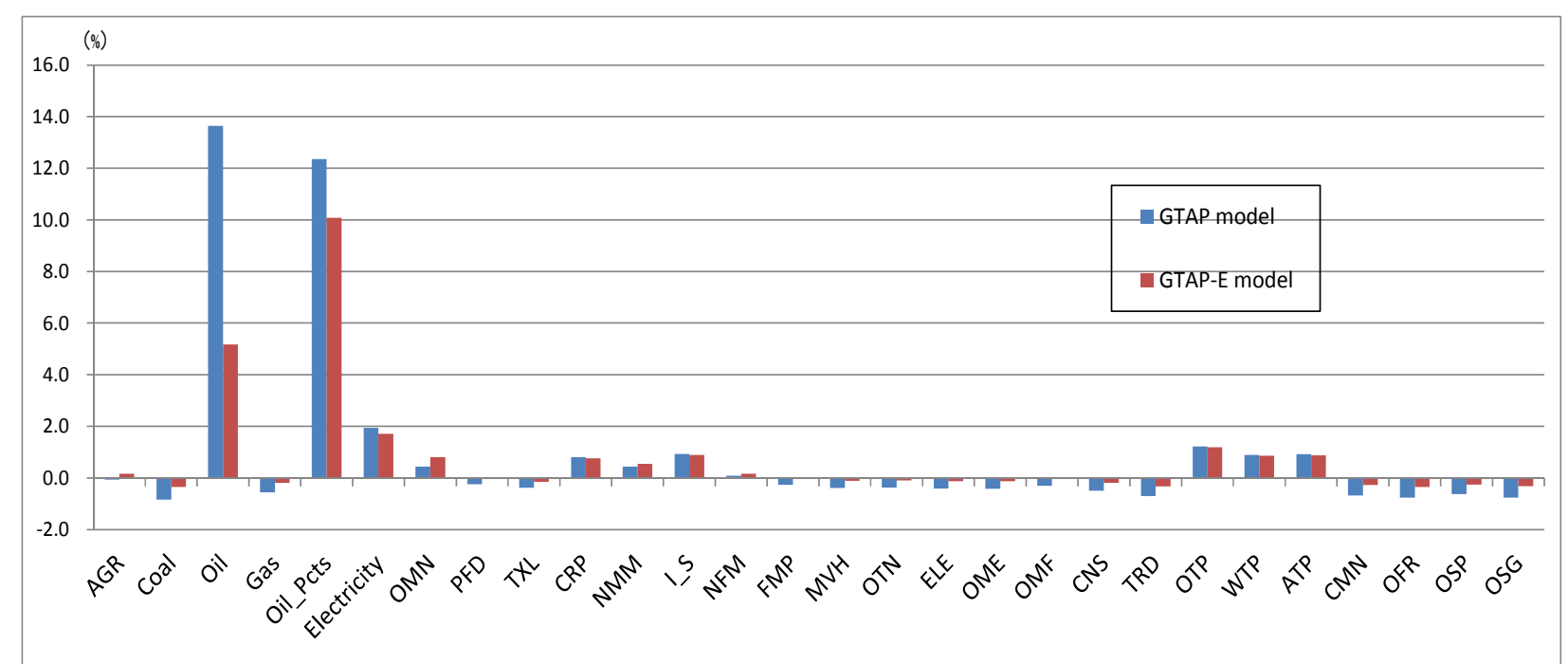

Figure 20. Impacts on Japan's supply price, with the capital accumulation effects, caused by a 25\% decrease in Japan's crude oil imports from the Middle East (percentage). Source: author.

Though the results for the supply price of non-energy goods in both models are similar, the results for energy goods, especially crude oil, are rather different. The crude oil price increases by $13.7 \%$ in the GTAP model, which is almost the same percentage change shown in the static analysis. However, the crude oil price in the GTAP-E model does not increase by as much, owing to the substitution structure in the capital-energy composite and in the energy composite, remaining at $5.2 \%$, which is almost the same change shown in the static analysis. As in the case of the static analysis, the difference in the supply prices of petroleum and coal products in the two models is also clear. The price of petroleum and coal products increases by $12.4 \%$ in the GTAP model, and by $10.1 \%$ in the GTAP-E model.

\section{Changes in Japanese Exports}

Figure $21^{9}$ shows the simulation results with regard to changes in Japanese exports, incorporating capital accumulation effects and evaluated as percentages. As per the results of the static analysis, the differences in the results for exports are relatively small in both models and almost all industries, with the exception of petroleum and coal products. In both models, exports increase in the non-energy-intensive sectors, such as

\footnotetext{
${ }^{9}$ In Figure 21, the results of the crude oil and gas sectors are not shown because they change significantly compared with the results in the other sectors. Crude oil exports decrease by $67.2 \%$ in the GTAP model, and by $37.8 \%$ in the GTAP-E model. The percentage change of gas exports is much less than that in the static analysis, increasing by $26.2 \%$ in the GTAP model, and by $10.2 \%$ in the GTAP-E model. However, the values of crude oil and gas exports are nearly zero.
} 
MVH (motor vehicles and parts), ELE (electronic equipment), and OME (machinery and equipment), but by less than in the case of the static analysis. Because the negative impacts in other sectors are stronger in the analysis incorporating capital accumulation effects, the total percentage change is smaller than that in the static analysis in both models.

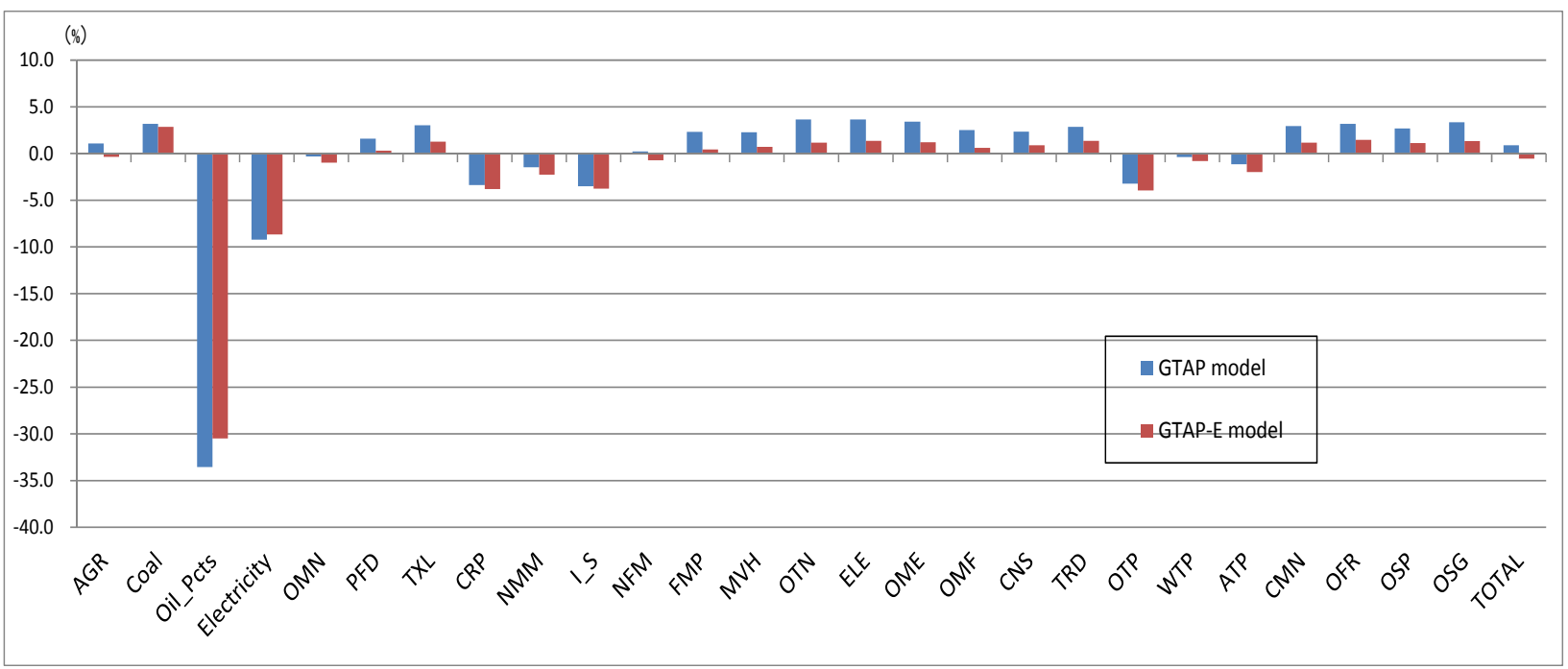

Figure 21. Impacts on Japan's exports, with capital accumulation effects, caused by a $25 \%$ decrease in Japan's crude oil imports from the Middle East (percentage). Source: author.

Figure 22 shows the simulation results of changes in Japanese exports (million USD). The positive impacts on non-energy-intensive goods and services surpasses the negative impacts on petroleum and coal products and energy-intensive goods. Thus, total exports becomes positive in the GTAP model. On the other hand, in the GTAP-E model, the decreases in petroleum and coal products and in energy-intensive goods are greater than the increase in non-energy-intensive goods and services. Thus, total exports becomes negative.

\section{Changes in Japanese Imports}

Figure 23 shows the changes in Japan's imports (market price weights), incorporating capital accumulation effects, evaluated as percentages.

As in the case of the static analysis, the difference between the simulation results of the GTAP model and the GTAP-E model is shown clearly in energy goods.

Reflecting the difference in the structure of energy goods, imports of crude oil decrease significantly more in the GTAP-E model than they do in the GTAP model.

Figure 24 shows the simulation results of changes in Japan's imports, incorporating capital accumulation effects and evaluated in millions USD. In both models, total imports decrease by slightly less than they do in the static model. When capital accumulation effects are incorporated, industrial outputs decrease by more than they do in the static model, as does the use of petroleum and coal products. As a result, Japan would depend more on imports. 


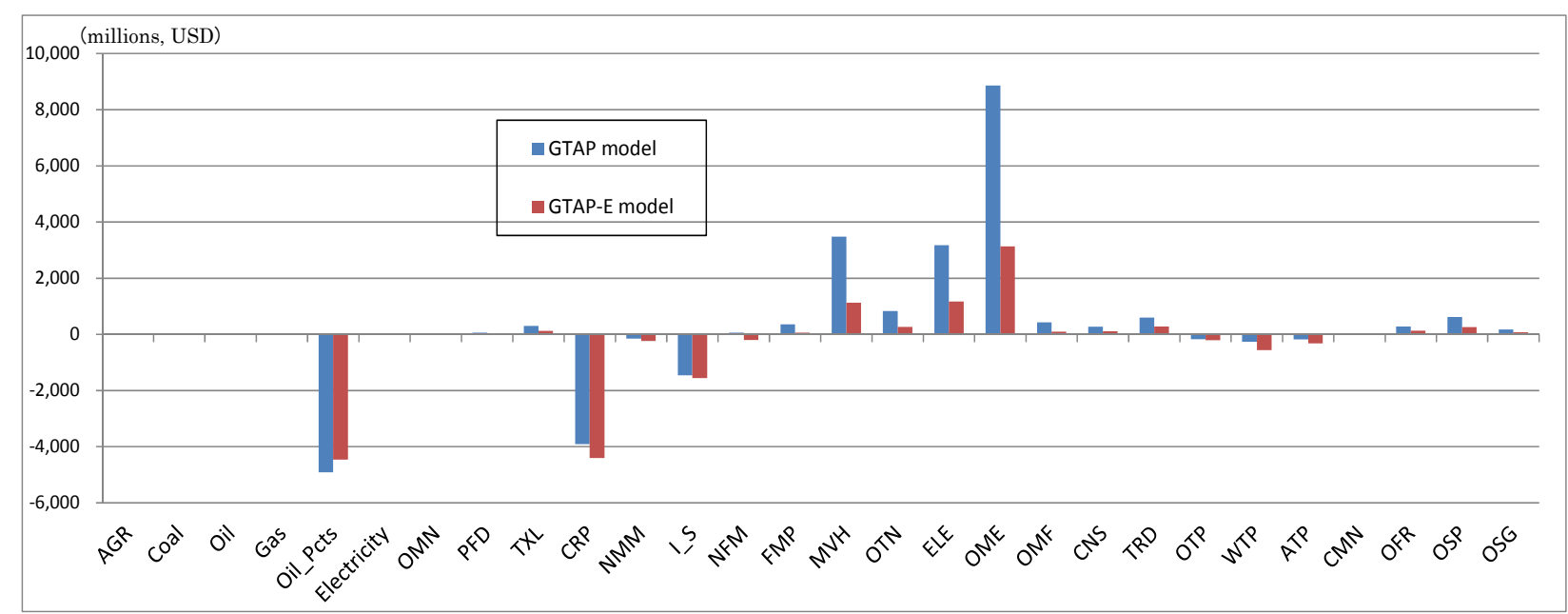

Figure 22. Impacts on Japan's exports, with capital accumulation effects, caused by a $25 \%$ decrease in Japan's crude oil imports from the Middle East (millions, USD). Source: author.

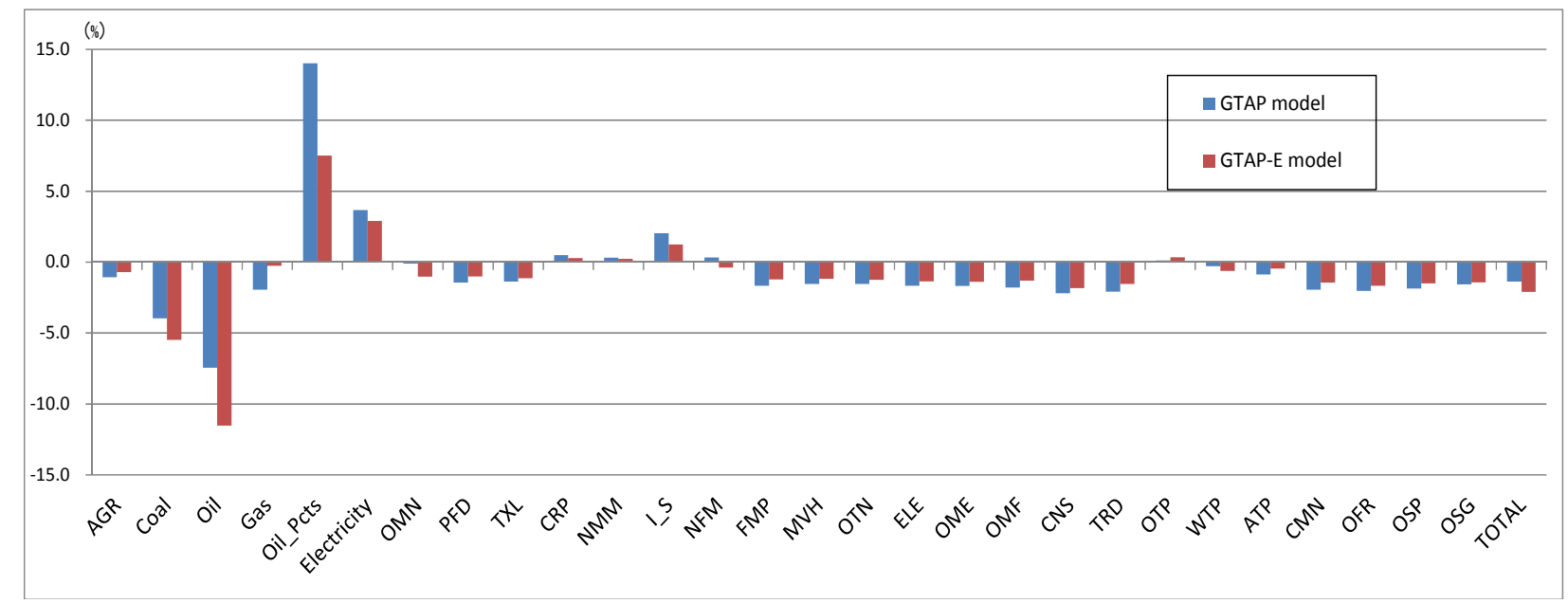

Figure 23. Impacts on Japan's imports, with capital accumulation effects, caused by a $25 \%$ decrease in Japan's crude oil imports from the Middle East (percentage). Source: author.

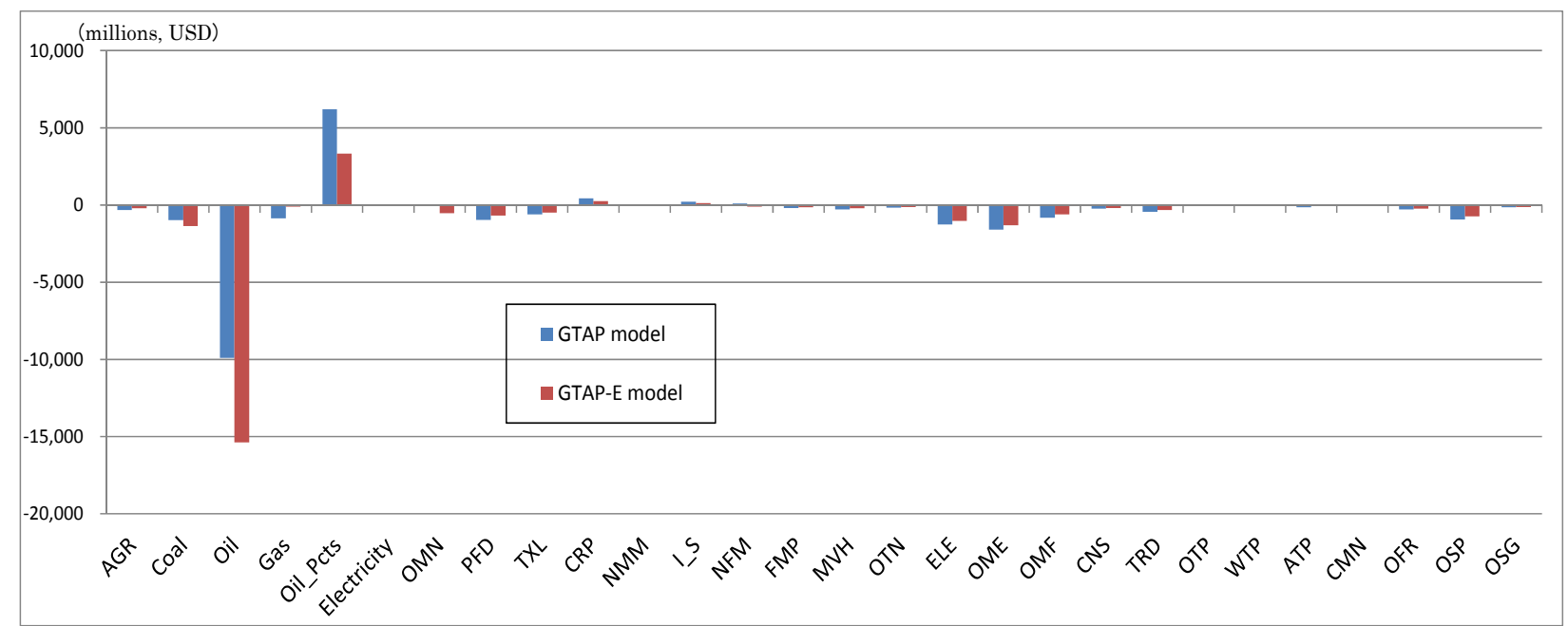

Figure 24. Impacts on Japan's imports, with capital accumulation effects, caused by a $25 \%$ decrease in Japan's crude oil imports from the Middle East (millions, USD). Source: author. 


\section{Conclusion}

This study analyzed the impact of a decrease in Japan's crude oil imports from the Middle East on the Japanese economy using the GTAP and GTAP-E models, as well as a static analysis and an analysis incorporating capital accumulation effects.

In the static analysis, the change in real GDP is $-0.53 \%$ for the GTAP model and $-0.59 \%$ for the GTAP-E model. The simulation results indicate that although the difference between the results of the two models in terms of real GDP is relatively small, the simulation results by industry and by commodity (especially for energy goods) show rather different tendencies.

The reason for this difference between the two models can be attributed to the difference in their production structures, where the GTAP-E model includes a structure for energy substitution. In the GTAP-E model, with its production structure in which crude oil can be substituted by other energy goods, when crude oil imports from the Middle East decrease, Japan would try to increase its crude oil imports from other regions, but by less than in the case of the GTAP model. Thus, the decrease in the production of petroleum and coal products, for which crude oil is important as feedstock, becomes more serious than in the GTAP model. This, in turn, causes a more serious decrease in industrial outputs than it does in the case of GTAP model.

The GTAP model, which does not have a structure for substitution between energy goods, treats energy goods as intermediate goods (i.e., as feedstock). Therefore, when the crude oil imports from the Middle East decrease, Japan will increase its imports of crude oil from other regions in the GTAP model, and the production of petroleum and coal products will decrease by less than it does in the GTAP-E model. The difference in the decrease of production of petroleum and coal both models.

When capital accumulation effects are incorporated, the difference between the results of the two models becomes a little larger and clearer than in the case of the static analysis. This difference is mainly because of the difference in the production structures of the two models.

In general, the GTAP-E model is suitable for analyzing energy goods because of its production structure of substitution between capital and energy goods and between energy goods themselves. However, when energy goods are used mainly as feedstock, the simulation results of the GTAP model, which treats energy goods as intermediate inputs only, present results that are more realistic. In Japan, 94\% of crude oil is used in petroleum and coal products and $6 \%$ is used for electricity. Thus, it would be better to use the GTAP model to analyze the impact of a decrease in crude oil imports on the Japanese economy, while referring to the results of the GTAP-E model, which treats energy goods as factors of production.

\section{References}

Agency for Natural Resources and Energy. (2014). Strategic energy plan (in Japanese). Retrieved from http://www.enecho.meti.go.jp/category/others/basic_plan/pdf/140411.pdf

Burniaux, J., \& Truong, P. T. (2002). GTAP-E: An energy-environmental version of the GTAP model. GTAP Technical Paper, 16. Retrieved from https://www.gtap.agecon.purdue.edu/resources/download/1203.pdf

Francois, J. F., Mcdonald, B. J., \& Nordström, H. (1996). Liberalization and capital accumulation in the GTAP model. GTAP Technical Paper, 7. Retrieved from https://www.gtap.agecon.purdue.edu/resources/download/40.pdf

Fujikawa, K. (1999). Micro-economic basis of input-output analysis and development of multi-sectoral model (in Japanese). Business Economy, 34, 133-164.

Guha, G. S. (2005). Simulation of the economic impact of region-wide electricity outages from a natural hazard using a CGE model. Southwestern Economic Review, 32, 101-124.

Hertel, T. W. (Ed.). (1997). Global trade analysis modeling and applications. New York, NY: Cambridge University Press. 
Hertel, T. W., Walmsley, T., \& Itakura, K. (2001). Dynamic effects of the "New Age" Free Trade Agreement between Japan and Singapore. GTAP Working Paper, 15. Retrieved from https://www.gtap.agecon.purdue.edu/resources/download/548.pdf

Higashi, A. (2016). Analysis of electric supply shortage and change in primary factors caused by earthquake using CGE model (in Japanese). Input-Output Analysis Innovation \& I-O Technique, 23(1-2), 44-54.

Higashi-Shiraishi, A. (2014). Impacts of electric supply shortage in Japan simulated by the GTAP, GTAP-E, and revised GTAP-E models. Journal of Business and Economics, 4, 550-571.

Ishikura, T., \& Ishikawa, Y. (2011). Spatial economic impacts of power supply shortage due to the East Japan Earthquake (in Japanese). Input-Output Analysis Innovation \& I-O Technique, 19(3), 51-59.

Rose, A., \& Guha, G. S. (2004). Computable general equilibrium modeling of electric utility lifeline losses from earthquakes. In Y. Okuyama, Y. and Chang, S. E. (Eds.), Modeling spatial and economic impacts of disasters (pp. 119-141). Springer-Verlag.

Rose, A., \& Liao, S. Y. (2005). Modeling regional economic resilience to disasters: A computable general equilibrium analysis of water service disruptions. Journal of Regional Science, 45, 75-112.

Tatano, H., Tsuchiya, S., \& Kajitani, Y. (2007). Measuring economic losses caused by lifeline disruption (in Japanese). Annuals of Disaster Prevention Research Institute, Kyoto University, 50B, 143-154.

United Nations. UN Comtrade Database. Retrieved from http://comtrade.un.org/ 